Minnesota Journal of Law \& Inequality

\title{
The Edges are Bleeding: Constitutional Proxies and Imprisoned Trans Bodies in Edmo and Gibson
}

Jen Davison

Follow this and additional works at: https://lawandinequality.org/

Law \& Inequality: A Journal of Theory and Practice is published by the University of Minnesota Libraries Publishing.

\section{LIBRARIES}

P U B L I H I N G 


\title{
The Edges are Bleeding: Constitutional Proxies and Imprisoned Trans Bodies in Edmo and Gibson
}

\author{
Jen L. Davison† \\ No one ever thinks of us as human \\ because we are more ghost than flesh, \\ because people fear that my gender expression is a trick, \\ that it exists to be perverse, \\ that it ensnares them without their consent, \\ that my body is a feast for their eyes and hands \\ and once they have fed off my queer, \\ they'll regurgitate all the parts they did not like. \\ They'll put me back into the closet, hang me with all the other \\ skeletons. \\ I will be the best attraction. \\ Can you see how easy it is to talk people into coffins, \\ to misspell their names on gravestones. ${ }^{1}$ \\ The human body historically has been conferred certain rights \\ in law. For centuries, rights, privilege, and status could accrue \\ only to male bodies (in some cases in British, European, and \\ American societies, only to Caucasian, light-skinned, male \\ bodies.) Women and other non-white men were chattels, \\ servants, or little more than beasts of burden, and were \\ frequently regarded as lacking the capacity to reason, even \\ lacking souls. Particular qualities: autonomy, authenticity, \\ authority, dignity — and rights: privacy, freedom, and equality- \\ attach to, or conversely are denied, a corporeal presence. ${ }^{2}$
}

†. J.D. Candidate (2021), University of Minnesota Law School; B.A., Honors English (2011), University of British Columbia; B.A., Religion (2008), Summit Pacific College. The author expresses gratitude to Professor Perry Moriearty, Stephanie Gruba, Abigail Hanson, Navin Ramalingam, Abigail Rauls, Alena Simon, Heather Chang, Ivy Marsnik, Gabrielle Maginn, Katie McCoy, Esther Raty, Jeremy Walls, Kristin Trapp, Kevin Thomson, Anna Berglund, James Holden, and to my partner, Micah Davison.

1. Lee Mokobe, A Powerful Poem About What It Feels to Be Transgender, Fine Acts Collective, https://fineacts.co/lee-mokobe [https://perma.cc/CXR2-CTX7].

2. Jamison Green, "If I Follow the Rules, Will You Make Me a Man?" Patterns in Transsexual Validation, 34 U. LA VERNE L. REV. 23, 24 (2012) (citation omitted). 
We hold these truths to be self-evident, that all men are created equal, that they are endowed by their Creator with certain unalienable Rights, that among these are Life, Liberty and the pursuit of Happiness. ${ }^{3}$

The endowment of certain unalienable rights for certain bodies was declared obvious by the Founding Fathers of the United States. More than 200 years later, the category of "men" whose rights were presumed has produced a long-fought war waged at battlefronts including slavery's abolition, women's liberation, and a front at hand-transgender rights. ${ }^{4}$ The $1960 \mathrm{~s}$ second-wave feminist movement and the 1970s intersex and transgender movements argued that identity and gender were social constructs, challenging "the essentialist biologically based conceptualization of gender" rigidly curtailing some bodies' rights. ${ }^{5}$ Nevertheless, American culture widely continued to view gender-nonconformism as a disorder, where only biologically-derived gender identities were normatively correct. ${ }^{6}$ The dissonance of these norms with the

3. THE DEClaRATION OF INDEPENDENCE para. 2 (U.S. 1776).

4. See Anne-Marie Cusac, Cruel and Unusual: The Culture of PUNISHMENT IN AMERICA 120 (2009) (observing second-wave feminism, gay liberation, and Black power caused increasing anxiety for cultural conservatives); see also Kevin M. Barry, Brian Farrell, Jennifer L. Levi \& Neelima Vanguri, A Bare Desire to Harm: Transgender People and the Equal Protection Clause, 57 B.C. L. REV. 507, 508 (2016) (noting the torch has been passed from LGB to T recently and the next civil rights frontier belongs to transgender people).

5. Mairéad Losty \& John O'Connor, Falling Outside of the 'Nice Little Binary Box': A Psychoanalytic Exploration of the Non-binary Gender Identity, 32 PsychoANALYTIC PsYchotheraPy 40, 41 (2018). The World Health Organization currently observes the social construction of gender as a known fact:

Gender, typically described in terms of masculinity and femininity, is a social construction that varies across different cultures and over time. There are a number of cultures, for example, in which greater gender diversity exists and sex and gender are not always neatly divided along binary lines such as male and female or homosexual and heterosexual. The Berdache in North America, the fa'afafine (Samoan for "the way of a woman") in the Pacific, and the kathoey in Thailand are all examples of different gender categories that differ from the traditional Western division of people into males and females. Further, among certain North American native communities, gender is seen more in terms of a continuum than categories, with special acknowledgement of "two-spirited" people who encompass both masculine and feminine qualities and characteristics. It is apparent, then, that different cultures have taken different approaches to creating gender distinctions, with more or less recognition of [the] fluidity and complexity of gender.

Genomic Resource Centre Gender and Genetics: Genetic Components of Sex and Gender, WORLD HEALTH ORG., https://www.who.int/genomics/gender/en/ index1.html [https://perma.cc/M98M-NB73].

6. Losty, supra note 5, at 41 (noting this is still the case in particular for nonbinary individuals where "legitimate" trans-persons are trans-men or trans-women); 
American ideals of equality and independence lingers, but recently there have been some dissonance-reducing gains for some Americans whose rights the Constitution has historically failed to protect. $^{7}$

If we take the Founding Fathers at their aspirational word, the Constitution's protections are for every American, regardless of their body. ${ }^{8}$ Constitutional protections are big ideas actualized by proxies. A proxy is "the agency, function, or office of a deputy who acts as a substitute for another." " Like representational signifiers for reality that gesture towards what is real, proxies are stand-ins for larger values that can be hard to realize in everyday lifeparticularly when their course flows through the rapids of normative social change. The law, its interpreters, and every doctrine and test they employ are such proxies.

Among such rapids of normative change, for decades courts have been considering whether the treatment of transgender ${ }^{10}$

see also Elvira Prusaczyk \& Gordon Hodson, The Roles of Political Conservatism and Binary Gender Beliefs in Predicting Prejudices Toward Gay Men and People Who Are Transgender, SEX ROLES 1, 2 (2019) (arguing that according to social dominance theory, societies are organized into hierarchical groups maintained through the legitimizing myths of rightly-apportioned power in hierarchy-enhancing ideologieswhich for Americans have been right-leaning ideologies that justify and rationalize prejudice and discrimination against non-Anglo, non-hetero, non-male bodies). Prusaczyk \& Hodson further observe that "[r]esearch shows that those on the political right tend to express more negativity toward LGBTQ+ people" driven by an epistemic need to protect their ideology through "resistance to change and opposition to equality." Id.

7. Gay marriage rights, for example, were recognized by the Supreme Court in Obergefell v. Hodges, 576 U.S. 644, 646 (2015). The Ninth Circuit's ruling in Edmo v. Corizon, Inc., 935 F.3d 757, 767 (9th Cir. 2019) (per curiam), is another such example-and is a focus of this Note.

8. THE DEClARATION OF INDEPENDENCE, supra note 3.

9. Proxy, MerRiam-WeBSter, https://www.merriam-webster.com/dictionary/ proxy [https://perma.cc/ALP7-MBRT].

10. See Dean Spade, Resisting Medicine, Re/Modeling Gender, 18 BERKELEY WOMEN's L.J. 15, 15-16 n.2 (2003). Recognizing words and naming have power as Spade suggests, this Note will use the terms "transgender" and "trans" as umbrella terms for people who "transgress the rules of binary gender." See Scott R. Chaiet, MD, MBA; Shane D. Morrison, MD, MS; Carl G. Streed, Jr., MD, Gender Confirmation Surgery and Terminology in Transgender Health, 152 JAMA SURGERY 1089, 1089 (2017). Accordingly, this Note will not use "transsexual," typically the medicalized term used to describe a subcategory among transgender people experiencing acute gender dysphoria often treated with hormones and surgery, because this term is outdated, stigma-reinforcing, and in the process of being retired by many national and international organizations. See Jens U. Berli, Gail Knudson, Lin Fraser, Vin Tangpricha, Randi Ettner, Frederic M. Ettner, Joshua D. Safer, Julie Graham, Stan Monstrey \& Loren Schechter, What Surgeons Need to Know About Gender Confirmation Surgery When Providing Care for Transgender Individuals: A Review, 152 JAMA SURGERY 394, 394 (2017) (putting some numbers to the 
imprisoned persons experiencing gender dysphoria (GD), ${ }^{11}$ including through gender confirmation surgery (GCS), ${ }^{12}$ falls within —or expands the definition of-medical necessity, activating Eighth Amendment protections against a deliberately indifferent government. ${ }^{13}$ This debate came to a head in 2019 when two federal circuit courts came to opposite conclusions on two cases of imprisoned persons experiencing severe GD. In Gibson v. Collier, the Fifth Circuit held that it was not cruel and unusual punishment for the State to deny GCS to an incarcerated individual named

population on which this Note will focus, approximately $0.4 \%$ to $1.3 \%$ of the population worldwide experiences gender dysphoria (GD)); see also Cynthia S. Osborne \& Anne A. Lawrence, Male Prison Inmates With Gender Dysphoria: When Is Sex Reassignment Surgery Appropriate?, 45 ARCHIVES SeXual BEHAV., 1649, 1649 (2016) (noting in Western countries, it is estimated that male-to-female (MtF) transgenderism is present in about 1 in 10,000 to 1 in 12,000, but research suggests a higher prevalence among male imprisoned persons in the U.S.); Yvette K. W. Bourcicot \& Daniel Hirotsu Woofter, Prudent Policy: Accommodating Prisoners with Gender Dysphoria, 12 STAN. J. C.R. \& C.L. 283, 286 (2016) (estimating the transgender population in the U.S. to be approximately 700,000 individuals, with $16 \%$ reporting being imprisoned at some point). But c.f. Osborne, supra, at 1650 (observing firsthand a prevalence of about 1 in 500 male imprisoned persons identifying as transgender, estimating that "there could easily be 3000-4000 males with GD in U.S. prisons"); Erin McCauley, Kristen Eckstrand, Bethlehem Desta, Ben Bouvier, Brad Brockmann \& Lauren Brinkley-Rubinstein, Exploring Healthcare Experiences for Incarcerated Individuals Who Identify as Transgender in a Southern Jail, 3 TRANSGENDER HeAlth 34, 34 (2018) ("One in six transgender individuals have been incarcerated at some point in their lives. For [B]lack transgender people, the rates of incarceration are even higher; some estimates indicate that nearly half (47\%) have been incarcerated at some point.").

11. See The Diagnostic and Statistical Manual of Mental Disorders 451 (Am. Psychiatric Ass'n ed., 5th ed. 2013) [hereinafter DSM-V] (explaining GD "refers to the distress that may accompany the incongruence between one's experienced or expressed gender and one's assigned gender"); see also AM. PSYCHIATRIC ASS'N, GENDER DYSPHORIA (2013), https://www.psychiatry.org/File\%20Library/ Psychiatrists/Practice/DSM/APA_DSM-5-Gender-Dysphoria.pdf (clarifying why the DSM-V replaced the category "gender identity disorder" in previous editions with "gender dysphoria" to officially recognize that gender nonconformity is not a mental disorder).

12. See Osborne, supra note 10, at 1650 (Gender Confirmation Surgery (GCS), also known as Gender Reassignment Surgery (GRS), Gender Reaffirming Surgery (GRS), Sex Confirmation Surgery (SCS), Sex Reassignment Surgery (SRS), a Sex Change Operation, Sexual Reassignment Surgery (SRS), or Bottom Surgery, encompasses surgical procedures performed to align an individual's primary and secondary sex characteristics aesthetically and/or functionally to resemble those of their gender identity). For a better understanding of surgical measures that may be taken-and how binary their conceptualization is in the medical field, see Berli et al., supra note 10, at 398. For an overview of related terminology, see generally Lee Harrington, Traversing Gender: Understanding Transgender Realities (2016) (ebook).

13. See Norsworthy v. Beard, 87 F. Supp. 3d 1164 (2015); De'lonta v. Johnson, 708 F.3d 520 (4th Cir. 2013); Fields v. Smith, 653 F.3d 550 (7th Cir. 2011); Maggert v. Hanks, 131 F.3d 670 (7th Cir. 1997); Meriwether v. Faulkner, 821 F.2d 408 (7th Cir. 1987). 
Vanessa Lynn Gibson. ${ }^{14}$ In Edmo v. Corizon, Inc., the Ninth Circuit held that GCS was medically necessary for an incarcerated individual named Adree Edmo and that responsible prison authorities were deliberately indifferent to this need in violation of the Eighth Amendment. ${ }^{15}$

This Note will explore this circuit rift and the arguments mobilized for and against locating GCS under Eighth Amendment protections. Part I will provide an overview of GD and GCS, a brief history of the principle of medical necessity and the Eighth Amendment, and a review of the Gibson and Edmo decisions. Part II will argue that the Ninth Circuit's decision to treat GCS as a medical necessity for Edmo, while problematic, is part of an objectively and normatively right progression that can and should be adopted by other circuits and the Supreme Court. Finally, Part III will explore what the Edmo and Gibson decisions are telling us about the American conscience, the dissonance between our Eighth Amendment ideals and the medical necessity proxy we use to actualize them, and the resulting need to elevate prison practices that induce self-harm or suicidality to proxies in their own right. Using medical necessity as a proxy for our Eighth Amendment consciences is producing mixed results that allow American citizens and legal professionals to tolerate cruel and unusual punishments.

\section{Background for the Edmo and Gibson Decisions}

In order to contextualize the Edmo and Gibson cases, this first Part will provide a brief historical context for these decisions, an overview of the GD both Edmo and Gibson experienced, and a description of the GCS they hoped to be evaluated for and/or receive. Since GD and GCS are medical in nature, they fall under the medical necessity doctrine as a proxy for Eighth Amendment protections, which will also be discussed here. This Part will then conclude with review of how each court applied the medical necessity doctrine to Edmo and Gibson.

\section{A. The Historical Context for Court-Ordered Gender Confirmation Surgery}

The Eighth Amendment, ratified in 1791, reads: "Excessive bail shall not be required, nor excessive fines imposed, nor cruel and

14. Gibson v. Collier, 920 F.3d 212, 215 (5th Cir. 2019).

15. Edmo v. Corizon, Inc., 935 F.3d 757, 767 (9th Cir. 2019) (per curiam). 
unusual punishments inflicted."16 It is understood to forbid practices contrary to eighteenth-century notions of civilized behavior through to today's contemporary social mores. ${ }^{17}$ Unfortunately, there is no one place we assemble our norms and then systematically realign our behaviors and institutions in society to match them. Even if there were, knowing the norms is not enough; you must also be aware of current practices to locate misalignments. When it comes to the criminal justice system, imprisoned persons and the punitive pains they suffer have become largely hidden from ordinary citizens who do not "recognize convicts as fully our own nor see the centrality of pain to our culture."18 This makes court cases an important window into the hidden experiences of incarcerated Americans with the potential to expose equally hidden dissonances with our prevailing norms.

It was not until 1976 that the Supreme Court considered the Eighth Amendment's protections for incarcerated individuals. ${ }^{19}$ In Estelle $v$. Gamble, the Court agreed that one key measure of such punishment is in the deprivation of medical care for a "serious

16. U.S. CONST. amend. VIII. Imprisoned persons who seek to challenge prison officials' decisions impacting their constitutional rights may bring either a $\S 1983$ or a Bivens action, depending upon whether the official is a state or federal employee, and may then seek damages and injunctive relief as per 42 U.S.C. $§ 1983$, which states:

Every person who, under color of any statute, ordinance, regulation, custom, or usage, of any State or Territory or the District of Columbia, subjects, or causes to be subjected, any citizen of the United States or other person within the jurisdiction thereof to the deprivation of any rights, privileges, or immunities secured by the Constitution and laws, shall be liable to the party injured in an action at law, suit in equity, or other proper proceeding for redress ... [, [,

or as per Bivens v. Six Unknown Named Agents of the Fed. Bureau of Narcotics, 403 U.S. 388, 395-96 (1971) (recognizing a similar cause of action to $§ 1983$ and allowing claims against federal actors).

17. Michael B. Mushlin, Rights of PRisoners 84-85 (5th ed. 2017) (discussing the history of what is objectively cruel and unusual punishment).

18. CUSAC, supra note 4, at 13; see also Sharon Dolovich, Cruelty, Prison Conditions, and the Eighth Amendment, 84 N.Y.U. L. REV. 881, 972 (2009) ("Banished into nonexistence, prisoners are noticed, if at all, only at the moment of sentencing or upon release, or when through an escape or some other notorious act they force themselves upon the public consciousness. But if the public benefits from this (temporary) freedom from the company of those deemed unfit to live in society, it does so only because the state commits to providing for the ongoing care and protection of the people society wishes to exclude during their incarceration."); $c f$. Brian Jarvis, Cruel AND Unusual: Punishment AND U.S. Culture 14 (2004) ("The mythology of the Land of the Free can be seen as an ideological smokescreen designed to obscure the systematic deprivation of liberty and infliction of punishments, both cruel and unusual.").

19. Mushlin, supra note 17, at 63 (discussing how the Court arrived at Estelle v. Gamble, 429 U.S. 97 (1976)). 
medical need,"20 coining the legal standard "deliberate indifference" that governs specific isolated actions of prison officials. ${ }^{21}$ According to the deliberate indifference standard, the State is required to provide a level of medical care that meets routine and emergency health care needs, including physical, dental, and psychological or psychiatric care. ${ }^{22}$ If an imprisoned person believes they are being denied or unreasonably delayed access to necessary medical care by deliberately indifferent state officials, they are entitled to claim that those officials violated the Cruel and Unusual Punishment Clause of the Eighth Amendment. ${ }^{23}$

Meanwhile in the medical world, 1979 saw the development of the first widely-recognized standards of care for persons experiencing gender identity dissonances, and as of 2020 these standards are in their seventh version. ${ }^{24}$ These World Professional Association for Transgender Health (WPATH) Standards of Care have a widely accepted treatment plan for those experiencing acute

20. The definition of what is a serious medical need remains vaguely defined and open to each court's subjective perception. Id. at 389-95. For a discussion of circuit treatment of GD, see Bourcicot, supra note 10, at 295-96 (arguing the majority of circuits recognize GD as a serious medical need, with the Fifth and Tenth Circuits as anomalies). See also Susan S. Bendlin, Gender Dysphoria in the Jailhouse: A Constitutional Right to Hormone Therapy, 61 CLEV. ST. L. REV. 957, 967 (2013) ("To the extent that the circuits differ, it is not over whether Gender Dysphoria constitutes a serious medical need, but over whether treatment is warranted in a specific case, and if so, what type of treatment should be provided. The objective prong of the test under $§ 1983$ - 'serious medical need'-can typically be satisfied by the inmate.").

21. Estelle v. Gamble, 429 U.S. 97 (1976) (creating the rule that deliberate indifference to an imprisoned person's serious medical needs by prison guards or doctors constitutes cruel and unusual punishment under the Eighth Amendment and gives rise to a civil rights cause of action under 42 U.S.C. $§ 1983$ ); see also MUSHLIN, supra note 17, at 65.

22. Bendlin, supra note 20, at 977 ("When the State takes someone into custody and deprives him of the ability to take care of himself, the State assumes some duty to provide for his basic needs such as food, shelter, clothing, personal safety, and medical care."); see also MUSHLIN, supra note 17, at 371-73 (noting incarcerated individuals are wholly dependent on prison staff for medical care, which is especially significant because studies suggest imprisoned persons have a higher than average need for medical care-both from statistically higher medical concerns coming into prison such as mental illness, HIV/AIDS, etc., as well as from the probability of sustained injuries and newly-arising health concerns during-and arguably resulting from-incarceration).

23. Estelle, 429 U.S. at 104-05.

24. Rudolph Alexander, Jr. \& Jacquelyn C. A. Meshelemiah, Gendered Identity Disorders in Prisons: What Are the Legal Implications for Prison Mental Health Professionals and Administrations?, 90 PRISON J. 269, 274 (2010). 
GD involving three sequential steps: 1) hormone therapy, 2) a period of time living as the opposite gender, and 3) GCS. ${ }^{25}$

It is important to note that some in the trans community and their advocates are resistant to the pathologizing of GD. ${ }^{26}$ Instead of understanding transgenderism as "a matter of natural diversity" that is not "inherently pathological or negative," the powerfully coercive force of the dominant binary understanding of gender relegates trans bodies to the unnatural. ${ }^{27}$ Those who do not conform to traditional gender binaries face pervasive social and economic discrimination, leading to a greater likelihood of being in the criminal justice system. ${ }^{28}$ Physicians-a small medical elite-have traditionally been our gatekeepers regulating gender nonconformity. Physicians control access to medical diagnostic categories that have reinforced sexist/heterosexist norms, recognizing only those who can narrate their gender experiences

25. World Prof'L Ass'N for Transgender Health, InC., Standards of Care For the Health of TRANSSEXUAL, TRANSGENDER, AND GENDER NONCONFORMing PEOPLE 1-7, 27-28 (7th ed. 2012), https://www.wpath.org/media/cms/Documents/ SOC\%20v7/Standards\%20of\%20Care\%20V7\%20-\%202011\%20WPATH.pdf?_t= 1605186324 [https://perma.cc/BYL6-PNJZ] [hereinafter WPATH]. For a discussion of criticisms of these standards, see Osborne, supra note 10, at 1650-51 ("Although they were formulated by experienced clinicians and scholars, most SOC recommendations are based on low-quality evidence, such as case series and expert opinion. The SOC also do not represent the experiences and practices of all GD experts, and some provisions of the SOC seem to reflect political considerations rather than scientific evidence or clinical experience." (citations omitted)).

26. See M. Dru Levasseur, Gender Identity Defines Sex: Updating the Law to Reflect Modern Medical Science Is Key to Transgender Rights, 39 VT. L. REV. 943, 952 (2015) (discussing transgender community feelings on their medicalization); see also Bendlin, supra note 20, at 961 ("The issue is a sensitive one because the diagnosis of Gender Dysphoria as a medical illness has a negative connotation to members of the transgender community. If, however, the condition is not recognized as an illness, then medical treatment may not be deemed necessary.").

27. Levasseur, supra note 26, at 946-47 (noting that "[t]his simplistic understanding of sex, as two fixed binary categories, is medically, scientifically, and factually inaccurate, but still broadly enforced by courts"); see also Marybeth Herald, Transgender Theory: Reprogramming Our Automated Settings, 28 T. JEFFERSON L. REV. 167, 169 (2005) ("[G]eneralizations about the biological differences between men and women often petrify into rigid and inaccurate stereotypes . . . so barnacled with associations that we can no longer separate out the purely biological from its cultural appendages."); Green, supra note 2, at 78 ("Visible external genitalia, presumed chromosomal make-up, and presumed reproductive capacity are viewed as primal, objective, fixed, and 'true' only because the external genitalia is the first observable differentiator-or characteristic of social significance-that people see in an infant. However, to define 'sex' as the fixed point of a compass that always tells us the 'truth' about a person is both archaic and naive.").

28. Sydney Tarzwell, The Gender Lines are Marked with Razor Wire: Addressing State Prison Policies and Practices for the Management of Transgender Prisoners, 38 COLUM. HUM. RTS. L. REV. 167, 167-68 (2006) (discussing transgender persons' exclusion from the legitimate economy). 
within those categories. ${ }^{29}$ Thus, like homosexuality, being transgender was placed in the American Psychiatric Association's DSM-V where the medical voice of authority originally called it a disorder. ${ }^{30}$ The trans community has fought for decades to see this stigmatization of transgenderism removed. ${ }^{31}$

Like homosexuality, GD has been migrating towards normalization. Homosexuality was removed as a disorder from the DSM in 1973, and the original Gender Identity Disorder (GID) was reclassified as GD in 2013, signifying a shift in understanding gender as distinct from binary sex. ${ }^{32}$ While mental distress or impairment is a common symptom or comorbid symptom of GD, many now claim it is an organic disorder that should be treated as a physical problem, not pathologized. ${ }^{33}$ While this progress is positive, the trans community still faces a serious medical/legal dilemma: ${ }^{34}$ rely on the Eighth Amendment to seek gender-affirming medical care but legitimize medical authority and reinscribe the problematic medical/legal model, 35 or insist on broader systemic change while - for the foreseeable future-sacrificing basic rights that include the right to medical care? ${ }^{36}$

29. Id. at 174 .

30. DSM-V, supra note 11; GENDER DYSPHORIA, supra note 11.

31. Walter Bockting, The Impact of Stigma on Transgender Identity Development and Mental Health, in GENDER DysPHORIA AND DisorDers OF SEX DEVELOPMENT: PROGRESS IN CARE AND KNOWLEDGE 319, 321-22 (Baudewijntje P. C. Kreukels et al., eds., 2014).

32. GENDER DYSPHORIA, supra note 11; Jack Drescher, Out of DSM: Depathologizing Homosexuality, 5 BEHAV. SCI. (BASEL) 565 (2015).

33. See Alexander, supra note 24, at 271 (discussing the push to depathologize GD).

34. See Silpa Maruri, Hormone Therapy for Inmates: A Metonym for Transgender Rights, 20 CORNELL J.L. \& PUB. POL’Y 807, 807 (2011) (observing that labeling GD as a mental illness is "a double-edged sword" that is "at odds with the transgender community's conceptualization of itself" because "while it allows access to hormone therapy, it does so by describing transgender individuals as somehow sick or infirm").

35. See Tarzwell, supra note 28, at 189 (discussing the medical/legal model of GD).

36. See Phyllis Randolph Frye, The International Bill of Gender Rights vs. The Cider House Rules: Transgenders Struggle with the Courts over What Clothing They Are Allowed to Wear on the Job, Which Restroom They Are Allowed to Use on the Job, Their Right to Marry, and the Very Definition of Their Sex, 7 WM. \& MARY J. WOMEN \& L. 133, 214 (2000) (including the right to competent medical and professional care regardless of "chromosomal sex, genitalia, assigned birth sex, or initial gender role"); see also G.A. Res. 217 (III) A, Universal Declaration of Human Rights (Dec. 10, 1948) (asserting the Declaration applies to everyone regardless of sex in Article 2 and affirming everyone's right to medical care in Article 25). Compare Stephen B. Levine, Reflections on the Legal Battles over Prisoners with Gender Dysphoria, 44 J. AM. ACAD. PSYCHIATRY L. 236, 240 (2016) (arguing these rights-based advocacy 


\section{B. An Overview of Gender Dysphoria and Its Medical Treatment}

The rise of transgender rights activism has been resisted as an assault on the United States' heteronormative empire, where assumptions about the stability of biological sex and residual Western philosophies of a sex-based natural order are gradually being called emperors with no clothes. ${ }^{37}$ Nevertheless, medical professionals have generally accepted standards of care for gendernonconformists-"based on the best available science and expert professional consensus" - that they can and should follow. ${ }^{38}$ WPATH, creator of the transgender Standards of Care, is an international multidisciplinary association promoting evidencebased clinical care for gender non-conforming people. ${ }^{39}$ WPATH asserts that the expression of gender characteristics is not something assigned by biological sex at birth, and its expression is not inherently pathological whether it conforms to that assigned sex or not. ${ }^{40} \mathrm{GD}$ is fundamentally an experience of being out-of-sync with that assigned sex at birth accompanied by the associated gender role and sex characteristics expected by society. ${ }^{41}$ When that dissonance rises to a significant level of distress, GD is diagnosed as acute and has indicated treatments. ${ }^{42}$ In the context of a social hierarchy that legitimizes and empowers traditionally genderconforming bodies, such dissonances are inevitable. ${ }^{43}$ Treatment for

approaches to trans medical care are harmfully agenda-driven because "[c]ombining science and advocacy produces problems" where "[s]cience provides a dispassionate view of what seem to be the facts" while "[a]dvocacy aims at attaining a specific goal, and it musters the facts that support that goal"), with Green, supra note 2, at 30 (arguing science only goes so far in changing norms because "[s]cientific discoveries are interesting, even exciting for some people, but they are heresies for others, dismissible, irrelevant, mere theories until they are validated by whatever system has been allocated greater authority").

37. See Rena Lindevaldsen, A State's Obligation to Fund Hormonal Therapy and Sex-rReassignment Surgery for Prisoners Diagnosed with Gender Identity Disorder, 7 LIBERTY U. L. REV. 15, 27-28, 45-47 (2012) (defending the heteronormative status quo and arguing science, medicine, and the law are being hijacked by politically liberal ideologies trying to "play[] God" by denying that "gender is an immutable trait, is binary in nature, and coincides from birth with an individual's sex" and that gender identity is something a child's family fosters "by teaching the child genderappropriate behavior").

38. WPATH, supra note 25 , at 1.

39. $I d$.

40. Id. at 4 .

41. Id. at 5 .

42. Id.

43. This Note follows the premise that American society has created the rigid rules that members of its society existentially cannot follow, then pathologized 
GD began in the second half of the twentieth century with a growth of awareness among medical professionals of the severity of the dissonances being experienced. ${ }^{44}$ Changes in gender expression, psychotherapy, hormone therapy, and surgery have been typical treatment options. ${ }^{45}$

To meet the currently accepted standards of care for a patient with GD, a medical professional must evaluate a patient's GD, provide information about treatment options and risks, assess and treat relevant mental health concerns, and then refer a patient for the chosen treatment. 46

GCS to change primary or secondary sex characteristics typically includes altering the chest/breasts, external or internal genitalia, facial features, or body contouring, ${ }^{47}$ and it is "often the last and the most considered step in the treatment process for gender dysphoria." 48 WPATH has found such surgeries to be indicated, effective, and medically necessary for some patients. ${ }^{49}$ To say these surgeries are medically necessary means that they are not merely elective procedures, ${ }^{50}$ but are provided only when patients

and/or punished the results. See CUSAC, supra note 4 (documenting the intertwined nature of Christianity and American cultural norms, including the protection and reinforcement of those norms through the scapegoating of norm-transgressors and their subsequent punishment). This ritual of the scapegoat-one who legitimizes and reinscribes an organizing myth through symbolic punishment-is a common theme in Christianity. See Leviticus 16:21-22 (telling how, in the Old Testament, the nation of Israel would send a sacrificial lamb into the wilderness to be killed once a year, heaped symbolically with their collective transgressions); John 1:29 (telling how, in the New Testament, Christ becomes this sacrificial "Lamb of God," heaped symbolically with the sins of the world). In the American myth, we orient and cleanse ourselves by sending Black Americans, those experiencing systemic poverty, and the gender nonconforming-among others - to prison, heaped symbolically with our culture's transgressions.

44. WPATH, supra note 25 , at 8 .

45. Id. at $9-10$.

46. $I d$. at $23-28$.

47. $I d$. at 10

48. Id. at 54. Of those opting for surgical treatment, satisfaction rates across studies ranged from $87 \%$ of male-to-female $(\mathrm{MtF})$ patients to $97 \%$ of female-to-male (FtM) patients, with regrets about this choice being an extremely rare $1-1.5 \%$ of $\mathrm{MtF}$ patients and $<1 \%$ of FtM patients. Id. at 8 .

49. $I d$. at $54-55$.

50. See Jody Marksamer \& Harper Jean Tobin, Standing with LGBT Prisoners: An Advocate's Guide to Ending Abuse and Combating Imprisonment, NAT'L CTR. FOR TRANSGENDER EQUAL., 55 (2013) ("[B]oth the American Medical Association ('AMA') and the American Psychological Association ('APA') have adopted public statements that reject the misconception that transition-related medical care is 'cosmetic' or 'experimental,' and recognize such care as effective, therapeutic, and a 'medical necessity ... for appropriately evaluated individuals.”) (citing AM. MED. ASS'N House of Delegates, AMA Resol. 122 (A-08) and AM. Psychol. Ass'N, APA Policy Statements on Lesbian, Gay, Bisexual \& Transgender Concerns (2009)). 
meet specific criteria: 1) persistent, well-documented GD; 2) capacity to give informed consent; 3) age of majority; 4) reasonably well controlled medical or mental health concerns; 5) twelve continuous months of hormone therapy; and 6) twelve continuous months of living in a gender role congruent with their gender identity. ${ }^{51}$ As some of these criteria suggest, GD is often accompanied by mental health concerns, including anxiety, depression, self-harm, a history of abuse and neglect, compulsivity, substance abuse, sexual concerns, personality disorders, eating disorders, psychotic disorders, and autistic spectrum disorders. ${ }^{52}$ When an individual with acute GD is denied the option for surgical intervention, they commonly experience depressive symptoms that may include suicidal ideation. ${ }^{53}$

The WPATH Standards of Care specify that "[h]ealth care for...gender-nonconforming people living in an institutional environment [such as prison] should mirror that which would be available to them if they were living in a non-institutional setting within the same community." ${ }_{4}$ As a result, prison policies regarding gender-nonconforming populations are in various stages of incorporating these new norms. ${ }^{55}$ The 2019 Edmo decision was the first time that a federal appeals court has ordered the State to pay for an incarcerated person's GCS under the Eighth Amendment. ${ }^{56}$

51. WPATH, supra note 25 , at 60 (noting that these are the criteria for a metoidioplasty or phalloplasty in FtM patients and for a vaginoplasty in MtF patients).

52. Id. at 24 .

53. See Osborne, supra note 10, at 1655 (documenting this suicidality indicator); see also:

I had come so far in my transition, and the actions by the hospital felt like a complete rejection of who I am. I had rejected myself for 29 years; having my surgery canceled brought back all of those feelings, despite five years of progress and acceptance. It made me feel like I wanted to crawl out of my own skin again.

Evan Minton, What It Was Like to Be Denied Medical Care Because of My Gender, VICE (June 29, 2018), https://www.vice.com/en_us/article/evk34n/denied-medicalcare-transgender-lawsuit [https://perma.cc/VC4M-KQ].

54. WPATH, supra note 25, at 67; see also Position Statement on Transgender Health Care in Correctional Settings, NAT'L COMM. ON CORR. HEALTH CARE (2009), https://www.ncchc.org/transgender-transsexual-and-gender-nonconforming-healthcare [https://perma.cc/X4GD-HU73] (suggesting that the proper approach to transgender medical care is to follow the WPATH Standards of Care).

55. See generally Tarzwell, supra note 28 (analyzing forty-four states' practices and policies on the management of transgender imprisoned persons).

56. Lateshia Beachum, Idaho Must Pay for an Inmate's Gender Confirmation Surgery, a Court Says. The Governor Is Fighting It., WASH. POST (Aug. 27, 2019), 


\section{The Eighth Amendment and Its Enforcement Through the Medical Necessity Doctrine}

The Eighth Amendment is a normative chameleon that prohibits "cruel and unusual" punishment. ${ }^{57}$ Early Supreme Court cases observed the difficulty of defining "cruel and unusual." The first proxy was a "manifestly cruel" standard which "forbade only the most extreme punishments" likened to torture-crucifixion, beheading, burning alive, quartering, disembowelment, and similar practices. ${ }^{58}$ In 1968, Judge Blackmun observed that "the limits of the Eighth Amendment's proscription are not easily or exactly defined," but that its "applicable standards are flexible," guided by "broad and idealistic concepts of dignity, civilized standards, humanity, and decency ...." 59 Thus, it absorbs its standards from the society around it; it is as cruel as we are.

The idea that incarcerated individuals have a right to health is also rooted in the Eighth Amendment.60 When a person is lawfully incarcerated, they are deprived of certain rights and privileges, but in general they still retain their constitutional protections. ${ }^{61}$ Specific to this Note's focus, under current interpretations, the State has an Eighth Amendment obligation to provide appropriate medical care for incarcerated persons. ${ }^{62}$ To fail

https://www.washingtonpost.com/dc-md-va/2019/08/27/idaho-must-pay-an-inmatesgender-confirmation-surgery-court-says-governor-is-fighting-it/

[https://perma.cc/9JHX-UURM] (reporting on this historic decision).

57. U.S. CONST. amend. VIII.

58. Bourcicot, supra note 10, at 290 (citing the Court's prohibition of such practices in In re Kemmler, 136 U.S. 436, 446-47 (1890) and Wilkerson v. Utah, 99 U.S. 130, 135-36 (1878)). See CUSAC, supra note 4, at 33, 48-49, 53, 99, 104, 212, 241 (noting that nevertheless, execution, physical restraints, gags, water punishments, beatings, pulley systems for stretching, sweat boxes, solitary confinement, and stun belts are just some of the range of cruelties that have been imposed on U.S. imprisoned persons-some disallowed, others lingering on, some disallowed and then reallowed, and some disallowed but likely to return). Though it is easy to think of these norms as linear progress, they are not. The progression of these cruelty norms is cyclical, with periodic resurgences of practices previously thought cruel and outmoded, such as the resurgence of solitary confinement. Id. at 63,241 .

59. Jackson v. Bishop, 404 F.2d 571, 579 (8th Cir. 1968).

60. Estelle v. Gamble, 429 U.S. 97, 102 (1976) ("Our more recent cases, however, have held that the Amendment proscribes more than physically barbarous punishments."). "Health," like what is "cruel and unusual," is a dynamic concept. It depends not only on appropriate clinical diagnosis and treatment for those experiencing GD such as Edmo and Gibson, but also on "social and political climates that provide and ensure social tolerance, equality, and the full rights of citizenship," necessitating "legal reforms that promote tolerance and equity for gender and sexual diversity and that eliminate prejudice, discrimination, and stigma." WPATH, supra note 25 , at $1-2$.

61. See Brown v. Plata, 563 U.S. 493, 510-11 (2011).

62. Estelle, 429 U.S. at 103. 
to do so would make imprisonment cruel. In this way, serious medical needs become proxies for suffering that is cruel to allow, where suffering has been medicalized into symptoms. Prison officials are given wide discretion in determining medical treatment for imprisoned persons and are presumed to be providing appropriate care.$^{63}$ However, when officials fail to provide necessary medical care with deliberate indifference to an imprisoned person's known serious medical need, the Eighth Amendment is violated. ${ }^{64}$ This proxy test for violation of the Eighth Amendment is known as the doctrine of medical necessity.

A person imprisoned who seeks to prove the violation of their Eighth Amendment protections embodied in medical necessity must meet both an objective and subjective threshold.65 They must objectively show that: 1) denying the needed medical care was against any competent recognized medical authority;66 2) at the time of denial they were experiencing a severe and obvious illness or injury; ${ }^{67} 3$ ) the denial was not due to mere negligence by the prison official(s), but demonstrates instead deliberate indifference; 68 and 4) resulting harm. 69 Thus, the objective threshold is a heavily fact-dependent analysis in which courts must

63. See, e.g., Kosilek v. Spencer, 774 F.3d 63, 96 (1st Cir. 2014); Jones v. Falor, 135 F. App'x 554, 556 (3d Cir. 2005).

64. Estelle, 429 U.S. at 104; Miller v. Calhoun County, 408 F.3d 803, 812 (6th Cir. 2005).

65. Smith v. Carpenter, 316 F.3d 178, 183-84 (2d Cir. 2003) ("The objective 'medical need' element measures the severity of the alleged deprivation, while the subjective deliberate indifference element ensures that the defendant prison official acted with a sufficiently culpable state of mind.").

66. Important to GD, the objective test requires that the medical treatment is necessary, not optional or elective, although more than mere labels are required to make an "elective" determination. See Garrett v. Elko, No. 95-7939, 1997 U.S. App. LEXIS 21271, at *3 (4th Cir. Aug. 12, 1997) ("[P] rison officials cannot avoid [E]ighth [A]mendment liability for denying a prisoner treatment necessary to address a serious medical need simply by labeling the treatment 'elective.").

67. The severity of the illness or injury being intentionally ignored is typically determined by a court through consideration of the effect of denying treatment. Miller v. Beard, 699 F. Supp. 2d 697, 707 (E.D. Pa. 2010).

68. Farmer v. Brennan, 511 U.S. 825, 836-37 (1994). See Dolovich, supra note 18, at 972-73 (discussing how Farmer shows the Supreme Court fundamentally misunderstands the collective bargain struck between the State and civil society when it "accord[s] state actors the same privilege of disregard and even obliviousness to the fate of imprisoned offenders that the public takes for granted"-resulting in a virtual "guarantee that the people being held in those prisons will suffer gratuitous physical and psychological harm").

69. E.g., Mayfield v. Craven, 433 F.2d 873, 874 (9th Cir. 1970) (the harm of permanent disfigurement); Kelley v. Hicks, 400 F.3d 1282, 1284 (11th Cir. 2005) (the harm of exposure to environmental tobacco smoke (ETS)). 
weigh each incarcerated individual's particular circumstances at the time of the alleged rights violation.

An incarcerated person must also subjectively show the State was deliberately indifferent to their serious medical need. "Deliberate indifference" to an imprisoned person's Eighth Amendment rights subjectively exists where a prison official: 1) knows of the person's treatment need but intentionally refuses to provide it; 2) delays necessary medical treatment for non-medical reasons; or 3) prevents the person from receiving needed or recommended treatment.70 "This does not mean that every prisoner complaint requires immediate diagnosis and care, but that, under the totality of the circumstances, adequate medical treatment be administered when and where there is reason to believe it is needed." 71 This subjective threshold is typically met when there is potential deprivation of life itself or infliction of permanent injuries. ${ }^{72}$ Thus, the bar for the doctrine of medical necessity is high.

\section{The 2019 Edmo and Gibson Decisions Created a Federal Circuit Split}

With this Eighth Amendment analysis in mind, this Note will turn to the facts and outcomes of the Ninth Circuit's Edmo and the Fifth Circuit's Gibson, two cases decided in 2019 in which incarcerated individuals experiencing acute GD alleged a violation of their Eighth Amendment rights under the doctrine of medical necessity.

70. Estelle v. Gamble, 429 U.S. 97, 104-05 (1976); see Farmer, 511 U.S. at 839 (likening the "cruel and unusual" standard under the Eighth Amendment to the subjective recklessness standard used in criminal law); see also Bourcicot, supra note 10, at 294 ("The wide discretion afforded prison officials allows them to weigh inmates' medical needs against ancillary factors-such as the availability of treatment, the cost of treatment, and administrative difficulties in administering treatment-without necessarily running afoul of the Eighth Amendment.").

71. Mills v. Oliver, 367 F. Supp. 77, 79 (E.D. Va. 1973); see Bourcicot, supra note 10, at 294 (stating prison officials have been found deliberately indifferent when they used cost as the sole basis for deciding not to provide treatment, when they consciously chose an "easier and less efficacious" treatment, when they ignored medical advice, or when "extreme bureaucratic inefficiencies or passive resistance" resulted in inadequate medical care).

72. See, e.g., McCollum v. Mayfield, 130 F. Supp. 112, 115 (N.D. Cal. 1955) (“A refusal to furnish medical care when it is clearly necessary, such as is alleged here, could well result in the deprivation of life itself; it is alleged that plaintiff suffered paralysis and disability from which he will never recover. This amounts to the infliction of permanent injuries, which is, to some extent, a deprivation of life, of liberty and of property. Since these rights are protected by the Fourteenth Amendment to the Federal Constitution, the complaint sufficiently alleges the deprivation of a right, privilege or immunity secured by the Constitution and laws of the United States."). 


\section{i. Adree Edmo's Ninth Circuit Case Affirmed GCS as a Medical Necessity}

In Edmo v. Corizon, ${ }^{73}$ the question before the court was whether GCS was medically necessary for Adree Edmo, a transgender incarcerated individual. ${ }^{74}$ The Ninth Circuit decision, a unanimous opinion written by Judges M. Margaret McKeown, Ronald M. Gould, and Robert S. Lasnik, observed that this question

73. Edmo v. Corizon, Inc., 935 F.3d 757 (9th Cir. 2019). This Note will focus on Parts I and III of the opinion, dealing with GD, GCS, medical necessity and the Eighth Amendment. Part II considers the Prison Litigation Reform Act, the injunction issued by the lower court, and mootness. To briefly summarize, the district court had granted injunctive relief ordering GCS. The Ninth Circuit affirmed that the district court made the "need-narrowness-intrusiveness" findings required under 18 U.S.C. § 3626(a)(1)(A) to maintain the injunction and thus, the appeal was not moot. Because the permanent injunction had not expired, but was simply stayed, the Ninth Circuit denied the State's motion to dismiss. Further, the injunction was held to be appropriate against the individuals in their personal or official capacities who participated in depriving Edmo of her Eighth Amendment rights. Id. at 782-84.

74. Adree Edmo was born in 1987 and grew up on the Shoshone-Bannock Indian reservation in Fort Hall, Idaho. LOCKED: I'm Not a Monster like Most People Think, BoISE ST. PUB. RADIO (episode 1, July 8, 2019), https://www.boisestate publicradio.org/topic/locked [https://perma.cc/ZWT9-43QP]; see Amended Complaint at 37, Edmo v. Idaho Dep't of Corr. (D. Idaho Sept. 1, 2017) (No. 1:17-cv-00151-BLW). Her mother, Michaeline "Micki" Edmo, testified in court she considered her own care of her children to have been sometimes inadequate, noting that she permitted them to be exposed to situations that she now regrets. LOCKED, supra. Described by those who knew her as a child as "strong-willed," "sassy," possessed of a "great sense of humor," and a lover of the musician Selena's work, Adree Edmo's gender identity was always complicated. Id. It was only as a young adult that she identified herself as "two-spirit." See Amended Complaint, supra at 39. "Two-spirit" is a newer term for the concept shared by some Native American tribes in which an individual identifies as both a male and a female- "tainna wa'ippe" on the Shoshone-Bannock reservation, literally translating "man-woman." LOCKED, supra. See also Harlan Pruden \& Se-ah-dom Edmo, Two-Spirit People: Sex, Gender \& Sexuality in Historic and Contemporary Native America, NAT'L CONG. AM. INDIANS POL'Y REs. CTR., http://www.ncai.org/policy-research-center/initiatives/Pruden-Edmo_TwoSpirit People.pdf [https://perma.cc/3LHR-NJVU]. Shoshone-Bannock elder and former judge, Clyde Hall, notes that traditionally many Native American cultures accepted those who did not conform to just one gender, but with colonization and the arrival of Christian missionaries, Native American peoples were told such non-binary people were an "abomination." LOCKED, supra. Since entering the criminal justice system, Edmo has apologized and expressed regret for her criminal actions, citing her alcoholism as a weakness that derailed her from her plans to become a physician. Id. "I'm not a monster like most people think," Edmo has stated. Id. When the Ninth Circuit decided in Edmo's favor, she released this statement: "I am relieved and grateful the court recognized my right to necessary medical treatment, and that I will get the surgery I need. I hope my case helps the State of Idaho understand that they can't deny medical care to transgender people." Press Release, Nat'l Ctr. Lesbian Rts., Federal Appeals Court Rules Idaho Department of Corrections Must Provide Gender Confirmation Surgery to Transgender Woman (Aug. 23, 2019), http://www.nclrights.org/press-room/press-release/federal-appeals-court-rulesidaho-department-of-corrections-must-provide-gender-confirmation-surgery-totransgender-woman/ [https://perma.cc/PA3R-8SSN]. 
invoked the Eighth Amendment that must normatively "take[ [into] account ... developing understanding"-in this case- "of increased social awareness" on "transgender health care." 75 The court affirmed the U.S. District Court for the District of Idaho finding that Edmo had established her ${ }^{76}$ Eighth Amendment rights were violated because GCS was medically necessary in her particular case. 77 The court ordered the State to provide the surgery. ${ }^{78}$ In doing so, Judges McKeown, Gould, and Lasnik acknowledged that their decision contradicted that of the Fifth Circuit in Gibson v. Collier, but observed the reason for the different outcome was that "Gibson relie[d] on an incorrect, or at best outdated, premise: that 'there is no medical consensus that GCS is a necessary or even effective treatment for gender dysphoria."79

Edmo's case facts read, at first glance, as a typical "case of dueling experts." 80 The supporting evidence for Edmo included that she was a MtF transgender imprisoned person, ${ }^{81}$ that she experienced GD because her sex at birth (male) was different from her gender identity (female), ${ }^{82}$ that this resulted in ongoing mental distress that limited her ability to function, 83 that she had a pattern of self-harm, ${ }^{84}$ and that twice she had attempted life-endangering self-castration. ${ }^{85}$ Experts established that Edmo's GD was a serious medical condition requiring the medically-recognized treatment of GCS. ${ }^{86}$ In doing so, they relied on the WPATH Standards of Care ${ }^{87}$ and agreed that while GCS is not the appropriate course of treatment for all who experience GD, Edmo's was acute and necessitated treatment through GCS. ${ }^{88}$ In their opinions, without

75. Edmo, 935 F.3d at 803.

76. This Note will follow the Ninth Circuit's use of Ms. Edmo's preferred female pronouns.

77. The Ninth Circuit specifically limits its decision to this set of facts. See Edmo, 935 F.3d at 767. However, the court holds that where a prison has "a de facto policy or practice of refusing treatment for gender dysphoria to prisoners," this would amount to deliberate indifference. $I d$. at 781 .

78. Id. at 803 .

79. Id. at 795 (quoting Gibson v. Collier, 920 F.3d 212, 223 (5th Cir. 2019)) (adding "[t]he Fifth Circuit is the outlier").

80. See id. at 787 .

81. Id. at 767 .

82. $I d$.

83. $I d$.

84. Id. at 774 .

85. Id. at 767 .

86. $I d$.

87. The court finds the WPATH Standards of Care "are the gold standard on this issue." $I d$. at $788-89$.

88. Id. at 767 . 
this treatment, Edmo would continue to suffer irreparable harm, both mentally and physically. ${ }^{89}$ Thus, failure to provide GCS constituted deliberate indifference in the face of Edmo's obvious ongoing suffering. ${ }^{90}$

The State argued that while Edmo's suffering met the threshold to trigger the Eighth Amendment, its agents were not deliberately indifferent to her suffering because they used medically-accepted standards of care to determine the appropriate course of treatment for Edmo was not GCS. ${ }^{91}$ The State's physician who treated Edmo, Dr. Scott Eliason, evaluated Edmo's GD in 2016 using the WPATH Standards and his own professional understanding of GD to determine GCS was not medically necessary. ${ }^{92}$ In his opinion, GCS would only be necessary where there was "(1) 'congenital malformations or ambiguous genitalia,' (2) 'severe and devastating dysphoria that is primarily due to genitals,' or (3) 'some type of medical problem in which endogenous sexual hormones were causing severe physiological damage." 93 Eliason had determined Edmo did not meet any of these criteria. ${ }^{94}$ The court found the State's evidence "illogical and unpersuasive." 95

The State also argued that its facility staff did not fail to act; rather, they were affirmatively providing medical care they believed to be appropriate. ${ }^{96}$ Eliason had prescribed treatment through hormone therapy and counseling, with continued monitoring and future assessments. ${ }^{97}$ This course of treatment was based on Eliason's belief that Edmo's mental health was not under the adequate control required to consider more serious interventions, such as GCS, as well as that Edmo had not lived in her identified gender role for twelve months in the world outside of prison. ${ }^{98}$ The

89. Id. at 776

90. Id. at 785 .

91. Id. at 773 .

92. Id. at $773-74$.

93. Id. at 773 .

94. Id.

95. Id. at 789. One of Edmo's experts, Dr. Ryan Gorton, testified that Eliason's three criteria were inconsistent with the WPATH Standards of Care: the first was inapplicable because it related to intersex conditions, not those experiencing GD; the second required severe and devastating gender-focused dysphoria when WPATH required only "clear and significant dysphoria;" and finally, the third was simply described as "bizarre." Id. at 778.

96. Id. at 793 .

97. Id. at 773 .

98. Id. at 774. These are among the WPATH criteria for GCS, supra note 25. 
court found this evidence unconvincing as well, concluding the State had indeed violated Edmo's constitutional rights. ${ }^{99}$

\section{ii. Vanessa Lynn Gibson's Fifth Circuit Case Denied GCS as a Medical Necessity}

In Gibson v. Collier, 100 the question the court chose to answer was whether the lower court erred in finding that there was "no genuine dispute as to any material fact" in the Eighth Amendment case brought by Vanessa Lynn Gibson ${ }^{101}$ and thus, that the lower

99. Id. at 792. The district court found that Edmo's self-harm was not evidence of a lack of mental health control, but rather evidence of a denial of medically necessary care. See id. at 781. The court agreed with experts who stated that there is no WPATH requirement that the twelve months of living in an identified gender role can only happen outside of prison. Id. Further, the court noted "a prisoner need not prove that he was completely denied medical care" to make out an Eighth Amendment claim. Id. (citing Lopez v. Smith, 203 F.3d 1122, 1132 (9th Cir. 2000) (en banc).

100. Gibson v. Collier, 920 F.3d 212 (5th Cir. 2019).

101. Vanessa Lynn Gibson has lived as a female since the age of 15 . Complaint at I 10, Gibson v. Livingston (W.D. Tex. June 8, 2015) (No. 6_15-cv-00190). Details available about Gibson's life prior to prison are few, but one source claims she had a seventh-grade educational level prior to being imprisoned and has the goal of becoming a paralegal. Scott Gibson \#699888, WRITEAPRISONER, https://writeaprisoner.com/inmates/scott-gibson-699888/education

[https://perma.cc/ZWG8-AMBX]. Once imprisoned, Gibson described her situation in an interview as follows:

I feel like my constitutional rights are being violated because [the TDCJ is] indiscriminately denying us medical care for no reason .... Having male genitalia, it makes me literally sick. I'm talking about to the point that I hate my life and it's an everyday thing.

David Artavia, Supreme Court Rejects Inmate's Case for Gender Confirmation Surgery, ADVOCATE (Dec. 10, 2019), https://www.advocate.com/transgender/2019/ 12/10/supreme-court-rejects-inmates-case-gender-confirmation-surgery

[https://perma.cc/RBV3-SQ]. Gibson had asked a prison physician if she could receive a sex-reassignment surgery and was told she could only be treated with hormones "because TDCJ-ID has a Ban on Sex Reassignment Surjery [sic]." Supra, Complaint at 20. When she was denied GCS, she asked prison officials if "she could have a pass to live as a female, to dress as a female and to keep her hair at least 7 inches long," but that, too, was denied. Id. at 9 23. While imprisoned, Gibson's art and poetry have been posted online. Justice for Vanessa Gibson, JUSTICE FOR VANESSA, https://justiceforvanessa.wordpress.com [https://perma.cc/B37W-6R3Z]. On the experience of being a transgender person, she wrote:

and I'm not ashamed of my tears / we have had our bones broken / faces smashed / eyes blackened / and faces sliced wide open, / and some of our bones will never be found / because they're rotting in a shallow grave / knowing this, / I refuse to be anyone you want me to be. / I'd rather die for our rights / then to let you win.

I See Your Hate, JUSTICE FOR VANESSA (Apr. 19, 2016), https://justicefor vanessa.wordpress.com/2016/04/19/i-see-your-hate-a-poem-by-vanessa/ [https://perma.cc/CPF5-T34Q]. After the Fifth Circuit's decision, Gibson wrote:

For years the court system have [sic] allowed prison officials to get away 
court correctly held the named state officials of the Texas prison were "entitled to judgment as a matter of law." 102 The Fifth Circuit's majority opinion, written by Judge James C. Ho, claimed to travel the well-trodden path of established precedent that the Eighth Amendment does not guarantee whatever medical care an imprisoned person requests. ${ }^{103}$ Instead, the care required by the Constitution is calibrated to "society's minimum standards of decency." 104 The substantive, normative question was whether the deprivation of GCS was against those minimum standards. ${ }^{105}$ The legal question was procedural: had the lower court impermissibly dismissed a case when there was a real dispute? 106 The majority affirmed the U.S. District Court for the Western District of Texas in finding that there was no genuine dispute of material fact because medical necessity rested on a medical treatment being indicated, and here the majority agreed there was no medical consensus for the treatment of GD on which to base medical necessity. ${ }^{107}$

The majority further argued if these procedural flaws were not sufficient dismissal grounds, the substance also allowed the court to dismiss Gibson's appeal as a matter of law. ${ }^{108}$ Judge Ho looked to the plain text and original meaning of the Eighth Amendment's "cruel and unusual" language and found that only what was routine, regular, or customary was "usual."109 Since "cruel and unusual" is conjunctively joined, cruelty alone was found permissible under the Eighth Amendment as long as it was not also unusual.110 Thus, evidence of Gibson's suffering that might otherwise indicate cruelty was present-self-harm and suicidality translated into medical symptoms-was irrelevant unless and until

with beating inmates, denying us medical care, murdering inmates, allowing gay inmates to be beaten and raped by coward ass gang members, and there is basically nothing we can do about it! If we can't trust the court and believe that it will protect us-what are we supposed to do?

Response to Lawsuit Dismissal: Gibson vs Brad Livingston, JUSTICE FOR VANESSA (Apr. 26, 2019), https://justiceforvanessa.wordpress.com/2019/04/26/response-tolawsuit-dismissal-gibson-vs-brad-livingston/ [https://perma.cc/M95H-D3FW].

102. Gibson, 920 F.3d at 219 (quoting FED. R. CIV. P. 56(a)). The district court was actually asked to decide summary judgment based on TDCJ's qualified immunity and Eleventh Amendment immunity claims, but also sua sponte decided summary judgment on the merits as well.

103. Id. at 216.

104. Id. (quoting Kosilek v. Spencer, 774 F.3d 63, 96 (1st Cir. 2014)).

105. $I d$.

106. Id. at 219 .

107. Id. at $223,226$.

108. Id. at 228.

109. Id. at 226-27.

110. Id. at 226 . 
most prisons in the U.S. routinely, regularly, or customarily provide GCS to incarcerated individuals. 111

Gibson, a MtF transgender imprisoned person ${ }^{112}$ and a pro se plaintiff, 113 was experiencing acute distress, depression, and selfharming urges that had risen to multiple attempted suicides. ${ }^{114}$ She ${ }^{115}$ asked the court to remand her case so that "[s]he [could] present evidence of [her] individual need for sex reassignment surgery." 116 She meanwhile provided the WPATH Standards of Care as support for her claim, as well as her affidavit, grievance records, psychiatric records, correspondence with her penitentiary healthcare team, and Texas Department of Criminal Justice (TDCJ) Policy G-51.11.117 TDCJ Policy G-51.11 required that Gibson, as a transgender imprisoned person, have her individual case and treatment evaluated by appropriate medical and mental health professionals using "[c]urrent, accepted standards of care." 118

Where Edmo is replete with case facts, Gibson is sparse. The TDCJ Director presented Gibson's grievance records, medical records, and G-51.11 to demonstrate Gibson received medical treatment according to G-51.11. ${ }^{119}$ While not cited by the State, the

111. Id. at 227 . This reductive grammatical argument fails to adequately capture the meaning of "cruel and unusual" because the two are not wholly discrete. They are more like a Venn diagram - and a Venn diagram in constant motion as society wrestles with its norms over time. Here, the Fifth Circuit insisted that if these particular legal norms change, it would not be through their courtroom, pinning the courtroom to courtrooms of the past. To be credible, the court needed to acknowledge that normative lines of the Eighth Amendment move and admit that their Circuit would move the line only when less change-averse sister circuits had already sufficiently paved the way.

112. Id. at $216-17$.

113. Id. at 218. It is possible Gibson's pro se status impacted the outcome of her case, although it is difficult to draw any meaningful conclusions from this procedural point that differentiates Gibson from Edmo.

114. Id. at 217.

115. Although the Fifth Circuit used male pronouns following the Texas Department of Criminal Justice, this Note will use Ms. Gibson's preferred female pronouns.

116. Id. at 223-24 (citing Oral Argument at 11:35-12:10, 13:27-16:22, Gibson v. Collier, 920 F.3d 212 (5th Cir. 2019)).

117. Id. at $220-21,232$.

118. Id. at 217-18 (citing Texas Department of Criminal Justice, Policy G-51.11: Treatment of Offenders with Intersex Conditions, or Gender Dysphoria, Formerly Known as Gender Identity Disorder (2017), https://www.tdcj.texas.gov/divisions/ cmhc/docs/cmhc_policy_manual/G-51.11.pdf [https://perma.cc/9UDQ-AS3F] [hereinafter G-51.11]).

119. Texas Department of Criminal Justice Step 1 Offender Grievance Form, Grievance No. 2015096265 filed by Scott L. Gibson (2015) ("Your allegation is unsubstantiated. You are receiving treatment for Gender Dysphoria per the policy ... G-51.11.”). 
Fifth Circuit invoked a persuasive First Circuit case from four years earlier called Kosilek $v$. Spencer, which found there was no medical consensus requiring provision of GCS to incarcerated individuals experiencing acute GD. ${ }^{120}$ Effectively importing Kosilek's fact record, Judge Ho used that case to find Gibson's mere preference for GCS was not a basis for a claim of deliberate indifference when the course of treatment was medically-disputed. ${ }^{121}$ The majority grounded its holding in its Eighth Amendment Fifth Circuit precedent that has historically rejected "claims in cases involving medical disagreement." 122 Without a medical consensus as per Kosilek, the court found the facts were all on TDCJ's side; Gibson raised no genuine dispute of material fact that her constitutional rights were being violated. ${ }^{123}$

In her dissenting opinion, Judge Rhesa Hawkins Barksdale argued that there are a number of problems with the majority's decision and that the case should have been remanded. ${ }^{124}$ First, the dissent observed procedural inadequacies. The lower court's summary judgment decision itself was improper under Rule 56(f) of the Federal Rules of Civil Procedure because its sua sponte departure from the basis for the motion to make its decision deprived Gibson of notice and a chance to respond. ${ }^{125}$ Additionally, both Judge Ho and the district court improperly placed the burden of discovery on Gibson, the non-moving party, rather than on the State as per summary judgment procedures. ${ }^{126}$ The State did not meet this burden because it failed to present evidence that showed

120. Gibson, 920 F.3d at 220-21 (citing Kosilek v. Spencer, 774 F.3d 63, 68 (1st Cir. 2014) and observing the First Circuit "exhaustively detailed the underlying expert testimony" to demonstrate "objective evidence that the medical community is deeply divided about the necessity and efficacy of sex reassignment surgery" in Gibson's case). While Kosilek included expert testimony that treated GCS both positively and negatively, the court simply notes the positive exists in one sentence after dedicating over a page and a half recounting the negative. Id. at 221-23.

121. Id. at 220, 226. Ironically, Gibson had not requested GCS as a treatment; she had asked to be medically evaluated and prescribed a course of treatment appropriate to her medical evaluation as per her original grievance form: "NOTE: I AM NOT REQUESTING A SEX CHANGE AT THIS TIME!" Texas Department of Criminal Justice Step 1 Offender Grievance Form, supra note 119. For similar reasoning to the Fifth Circuit here on patient preferences, see also Lamb v. Norwood, 899 F.3d 1159, 1161 (10th Cir. 2018) (holding an imprisoned person named Michelle Renee Lamb, who was born male but identifies as female, was not entitled to GCS because her current hormone and counseling treatments were determined to be adequate by prison officials despite Lamb's strong disagreement).

122. Gibson, 920 F.3d at 225.

123. Id. at 224 .

124. Id. at 228 .

125. Id. at $228-30$.

126. Id. at 231 . 
the absence of a dispute. ${ }^{127}$ The majority also improperly borrowed evidence from Kosilek to support the State-a past case that the State did not cite as support in district court. ${ }^{128}$ Thus, where the lower court improperly offered a sua sponte decision for the defendant, here the majority improperly offered a sua sponte fact record for the defendant. Additionally, in the territory of the Eighth Amendment that is sensitive to changes in norms over time, substituting a past case's fact record to presume present norms is inappropriate. ${ }^{129}$ Indeed, Judge Barksdale cited to the District of Idaho's Edmo decision to demonstrate that the normative winds showed a change since Kosilek. ${ }^{130}$

In addition to identifying these procedural errors, the dissent argued that the majority erred in formulating its substantive question as well. The question was not whether there was a lack of medical consensus about GCS, but "whether there [was] a disagreement about the efficacy of the treatment for this particular prisoner, based on this prisoner's individual needs." 131 Because the Eighth Amendment requires a fact-specific inquiry, the majority could not affirm a lower court that decided such a case without the facts-and it certainly could not affirm it by substituting in facts from another case. ${ }^{132}$ In fact, it remained unclear what Gibson's individual medical needs were, since G-51.11 "prohibit[ed] [imprisoned persons] from even seeing a Doctor to be evaluated to see whether or not they need Sex Reassignment Surjery [sic] to adeqaty [sic] treat their illness." 133 Gibson wanted to be evaluated, the very medical care guaranteed to her by G-51.11, and the very information required for the court to make an indifference determination. ${ }^{134}$ Instead of recognizing such evaluative evidence was necessary to decide the merits of Gibson's case, the majority instead nonsensically considered Kosilek's medical needs as per her

127. Id. at 232 .

128. Id.

129. Id. The majority argues that "[t]here is no reason why-as a matter of either common sense or constitutional law-one state cannot rely on the universally shared experiences and policy determinations of other states." Id. at 224. The convincing Supreme Court counterargument to this, given by Judge Blackmun over fifty years earlier, is that the Eighth Amendment is norm-sensitive. Jackson v. Bishop, 404 F.2d 571,579 (8th Cir. 1968).

130. Id. at 234 (citing Edmo v. Idaho Dep't of Corr., 358 F. Supp. 3d 1103, 1127 (D. Idaho 2018)).

131. Id. at 240 .

132. Id

133. Complaint at $₫$ 27, Gibson v. Livingston, 2016 U.S. Dist. LEXIS 195724 (W.D. Tex. Aug. 31, 2016) (No. W-15-CA-190).

134. Gibson, 920 F.3d at 233. 
medical experts. ${ }^{135}$ However, Kosilek and Edmo were evaluated individually, and the dissent opined that Gibson should also have been evaluated based on her own medical needs. ${ }^{136}$ Finally, the dissent noted that the Fifth Circuit was not at liberty to perform an originalist analysis of the proxies for the Cruel and Unusual Punishment Clause of the Eighth Amendment because the Supreme Court already established those standards in 1976 through Estelle. ${ }^{137}$

Two Circuits enforcing two markedly different rights standards for two Americans within the space of a few months of each other, but just one governing law: the Eighth Amendment. What makes Edmo's treatment cruel and unusual as decided in 2019, and how can that be reconciled with the dismissal of Gibson's similar case that same year? Where should the Supreme Court align itself given the circuit divide? The next Part of this Note will explore the tensions at play in these cases and argue that the Ninth Circuit's decision, while still problematic, is normatively right and should be adopted by the Supreme Court. ${ }^{138}$

\section{The Reasons Why the Supreme Court Should Follow Edmo's Lead}

This next Part will analyze each court's application of the doctrine of medical necessity to illustrate that the Ninth Circuit correctly applied the doctrine, whereas the Fifth Circuit did not. While this might provide some indication of which Circuit's precedent the Supreme Court should follow, the current conservative-leaning Court may hold out additional challenges against adopting a stance that could be viewed as sociallyprogressive. Thus, this Part will also discuss and rebut arguments

135. Id. "The majority apparently believes Gibson was never entitled to due process for this claim because Kosilek, an out-of-circuit opinion, has foreclosed any advancement in the law and medical research in this area." Id. at 238.

136. Id. at 237. In fact, TDCJ's Dr. Greene wrote a clinic note in Gibson's file that read: "Please schedule [Gibson] with unit MD for evaluation for referral for sex change operation and evaluation for medical pass for gender identity disorder." Id. The evaluation never occurred because G-51.11 was understood to not allow it. Id. The dissent argued this alone likely provided sufficient grounds to allege indifference. $I d$. at 239 .

137. Id. at 242 (citing Estelle v. Gamble, 429 U.S. 97, 104 (1976)). The dissent's exasperation is clear; the majority has needlessly waxed eloquent on Eighth Amendment standards while refusing to correctly apply them.

138. The Supreme Court did not take up either Gibson or Edmo for appeal. Gibson v. Collier, 205 L.Ed.2d 384 (U.S. 2019); Idaho Dep’t of Corr. v. Edmo, No. 19-1280, 2020 U.S. LEXIS 4867 (Oct. 13, 2020). 
that might be employed in the Supreme Court to defend following the Fifth Circuit's more conservative Gibson decision.

\section{A. The Ninth Circuit Correctly Applied the Doctrine of Medical Necessity}

Since the facts of Edmo and Gibson were strikingly similar, the question of which Circuit made the right decision is primarily a question of law: Which Circuit applied the medical necessity doctrine correctly? The first step to answering this question requires a review of the circumstantial facts that surrounded the denial of GCS to Edmo and Gibson: What symptoms had prison staff observed? What were their current medical diagnoses? What harmful effects were being risked by the denial of GCS?139

In Edmo, the Ninth Circuit discussed the symptoms of acute GD that Edmo experienced at length. ${ }^{140}$ These included distress "that impairs or severely limits the person's ability to function in a meaningful way" reaching a threshold that requires intervention; ${ }^{141}$ that causes an individual to feel depressed, embarrassed, disgusted, tormented, and hopeless, ${ }^{142}$ potentially leading to coping mechanisms including addiction, self-harm, or suicide; ${ }^{143}$ that is an "everyday recurring thought," 144 including regular thoughts of selfharm; ${ }^{145}$ that may lead to self-medication, including "cutting" one's body because "the physical pain helps to ease the "emotional torment' and mental anguish."146 Without "an appropriate treatment plan[,] [GD] can expose ... individuals to a serious risk of psychological and physical harm;" 147 and risks "further emotional decompensation," 148 "ongoing mental anguish and possible physical harm,"149 and "debilitating distress, depression, impairment of function, substance use," "self-injurious behaviors," and suicide. ${ }^{150}$

139. For generally accepted medical steps that should guide such questions, see WPATH, supra note 25 , at $23-28$.

140. Edmo v. Corizon, Inc., 935 F.3d 757, 772-73 (9th Cir. 2019). But see Levine, supra note 36, at 244 (arguing we should mistrust these facts about representations of psychological pain because they may frequently be the manipulations of individuals with pathologies fueling a "motive to annoy").

141. Edmo, 935 F.3d at 769 (quoting the DSM-V, supra note 11, at 453, 458).

142. Id. at 772 .

143. Id. at 773 .

144. Id. at 772 .

145. Id. at 774 .

146. Id.

147. Id. at 771 .

148. Id. at 787 .

149. Id. at 785 .

150. Id. at 769 . 
In this detailed context, Edmo's physician knew Edmo had clinically "significant" distress leading to repeated self-castration attempts likely to continue, and yet did not reevaluate or change the ineffective treatment plan. ${ }^{151}$ Thus, the court had little trouble affirming the district court's finding that the State was deliberately indifferent to Edmo's GD when-despite full knowledge ${ }^{152}$-it denied her the generally accepted treatment in the face of the present and future risk of serious harm.153 That deliberate indifference was cruel and unusual punishment.

In contrast, the Fifth Circuit appeared fact-averse in its Gibson decision. The court offered a cursory review of GD, noting symptoms included "clinically significant distress or impairment in social, occupational, or other important areas of functioning." 154 Judge Ho then observed Gibson had demonstrated acute distress, depression, attempts to castrate or otherwise self-harm, suicidal ideation, and three suicide attempts. ${ }^{155}$ The majority noted that while these symptoms were observed, it was not Gibson's specific symptoms that were critical to the case; rather, it was G-51.11.156 G-51.11 did not designate GCS as the treatment protocol for Gibson, and so the medical staff were not deliberately indifferent in providing it to her despite her known symptoms. ${ }^{157}$ Of this blanket, categorical denial, the Edmo court observed that such a "de facto policy or practice... amounts to deliberate indifference" in and of itself. ${ }^{158}$ The Gibson court thus fails to apply the medical necessity doctrine correctly because its conclusion relies on the wrong facts; it is not prison policy that determines medical care, but an assessment of an individual's particular serious medical needs in light of generally-accepted treatments-regardless of whether the prison policies accept those treatments or not. ${ }^{159}$

Once the circumstantial facts regarding an individual's observed symptoms, diagnoses, and risks of harm have been reviewed, a court also must determine what the accepted course of medical treatments are and if one was appropriately selected given

151. Id. at 793 .

152. Id. at 767 .

153. Id. at 781 .

154. Gibson v. Collier, 920 F.3d 212, 217 (5th Cir. 2019) (quoting the DSM-V, supra note 11 , at 453$)$.

155. Id. at $217,219$.

156. Id. at $223-24$.

157. Id. at $217-18$.

158. Edmo, 935 F.3d at 781, 796-97.

159. Id. at 797 (citing Kosilek v. Spencer, 774 F.3d 63, 91 (1st Cir. 2014)). 
these facts. ${ }^{160}$ Both the Fifth and Ninth Circuits agreed that if there are widely accepted medical treatment standards for GD, these set a chain reaction in motion for potential Eighth Amendment claims. ${ }^{161}$ The primary tension here is that the Fifth Circuit showed a marked resistance to accepting that such standards exist and include GCS, whereas the Ninth Circuit was among a majority consensus that accepts there are such standards. ${ }^{162}$ This makes sense given that normative changes see resistance, but at this point it is a weak argument that transgender medical care has not been widely accepted. ${ }^{163}$ The Ninth Circuit observed this, noting that the

160. The medical system and its treatments are often portrayed as providing equal care for all bodies, but we know this is not the case. Comedian and political commentator John Oliver recently observed that "if you are a woman and/or a person of color in the US, you may well have a very different relationship to our healthcare system than a white man." Adrian Horton, John Oliver: Bias in Medical Care Is a 'Discussion That We Need to Have', The Guardian (Aug. 19, 2019), https://www.the guardian.com/culture/2019/aug/19/john-oliver-last-week-tonight-recap-medical-

care-bias [https://perma.cc/HEM4-BQRA]. This is because biases have profoundly shaped the medical field through the use of the White male body as a stand-in for all bodies in the studies that have resulted in our medical diagnoses criteria. Id. Such biases have caused misdiagnoses and a needless "mortality gap" for non-White, nonmale bodies. See, e.g., Lili Barouch, Heart Disease: Differences in Men and Women, JOHNS HOPKINS MED., https://www.hopkinsmedicine.org/heart_vascular_institute/ centers_excellence/womens_cardiovascular_health_center/patient_information/heal th_topics/heart_disease_gender_differences.html [https://perma.cc/MV4F-6PML]; Roni Caryn Rabin, Huge Racial Disparities Found in Deaths Linked to Pregnancy,

N.Y. TIMES (May 7, 2019), https://www.nytimes.com/2019/05/07/health/ pregnancy-deaths-.html [https://perma.cc/DB4J-W4KN]. These biases have also led to a medical community that lacks knowledge about transgender bodies as well:

It is simply easier to say "we don't know" than it is to apply resources to verify a physical origin of [transgenderism], especially when only a relative few people are affected.... [N]ot knowing contributes to the ease with which trans people continue to be marginalized and treated as less than human. Not knowing also allows for religious opinion to be asserted as fact, and for the media to exercise its imagination in search of profits at trans people's expense.

Green, supra note 2, at 84 .

161. Gibson, 920 F.3d at $223 ; E d m o, 935$ F.3d at 787.

162. Gibson, 920 F.3d at $223 ; E d m o, 935$ F.3d at 795 .

163. The WPATH Standards of Care have been accepted by:

the American Medical Association, the American Medical Student Association, the American Psychiatric Association, the American Psychological Association, the American Family Practice Association, the Endocrine Society, the National Association of Social Workers, the American Academy of Plastic Surgeons, the American College of Surgeons, Health Professionals Advancing LGBTQ Equality, the HIV Medicine Association, the Lesbian, Bisexual, Gay and Transgender Physician Assistant Caucus, and Mental Health America.

Edmo, 935 F.3d at 769; see also Bourcicot, supra note 10, at 307 ("Sex reassignment surgery has been accepted in the medical community for decades as an appropriate and sometimes necessary treatment for gender dysphoria."). Interestingly, the WPATH Standards of Care are actually cited in G-51.11 itself, a fact seeming to contradict the Fifth Circuit's position. G-51.11, supra note 118. 
Fifth Circuit was the outlier fighting the last battle against this change. ${ }^{164}$ Indeed, the labors the Fifth Circuit's resistance required in Gibson are a window into the effort and tools courts may use to defend an increasingly untenable status quo. The dissent in Gibson rightly identified a procedural breach of summary judgment rules, a refusal to allow the case facts to be presented, a substitution of facts from an entirely different case, and an insistence that while reviewing the merits of the case was beyond the case's scope, nevertheless ink would be spilled on the merits in order to cement the Eighth Amendment in place-a futile, Sisyphean task to arrest a clause built to move over time. The Supreme Court will need to contend with the reality of an existing medical consensus which strongly favors following the Edmo court's decision.

Once there is an accepted medical treatment-which the Fifth Circuit does not admit-medical necessity claims require that treatment must then be delayed, denied, or otherwise hampered by officials who know or should know the care the particular individual's case necessitates. ${ }^{165}$ This denial cannot simply be negligent but must be knowing and intentional. ${ }^{166}$ Here, the Gibson court argued GCS was not an accepted treatment, and therefore could not be delayed, denied, or otherwise hampered by the State. ${ }^{167}$ The Edmo court, accepting the WPATH Standards, found Eliason's refusal to follow them and to provide GCS treatment when Edmo's GD showed acute symptoms amounted to deliberate indifference. ${ }^{168}$ Thus, when the Supreme Court faces a question of medical necessity for GCS, the outcome will largely depend on whether it accepts that GCS is a valid medical treatment.

\section{B. Why Might the Supreme Court Resist Edmo and Follow Gibson?}

The Ninth Circuit observed that it was "not the first to speak on the subject [of transgender health care], nor [would it] be the last."169 The Supreme Court can, and likely will, speak on the

\footnotetext{
164. Edmo, 935 F.3d at 795 . Green argues that in the twenty-first century, we are seeing a legal trend where such medically-based arguments have seen "traction in securing affirmative recognition for trans people and their civil (in the U.S.) or human rights (in the U.K. and Europe)." Supra note 2, at 63-64.

165. Estelle v. Gamble, 429 U.S. 97, 104-05 (1976).

166. Farmer v. Brennan, 511 U.S. 825, 836-37 (1994).

167. Gibson, 920 F.3d at 228.

168. Edmo, 935 F.3d at 797.

169. Id. at 803 .
} 
subject to resolve this circuit split in the future. ${ }^{170}$ The previous section details the Ninth Circuit's persuasively superior use of the medical necessity doctrine to suggest the Supreme Court should follow its precedent as a matter of law. Nevertheless, while unlikely to repeat the gross procedural irregularities of the Fifth Circuit, there are counterarguments that a majority conservative Supreme Court might rely on to delay realizing these new gender norms for an unpopular incarcerated subpopulation.

Behind a number of the following arguments is the premise that what is happening within trans medical standards of care is either the apolitical, scientifically fact-based, morally-right status quo of pathologizing GD through an impartial, binary sex-based assessment, or the political, advocacy-driven, norm-upsetting minority rights agenda usurping it. ${ }^{171}$ Yet science is not apolitical, facts must be selected for use or left to disuse, and knowledge advances through the questions normatively permitted and funded. ${ }^{172}$ Raising the accusation that for medical science to explore non-binary gender is for medicine to become political is thus a false claim. Furthermore, the claim that even when trans health is

170. Mushlin, supra note 17 , at 490 . A writ of certiorari may be granted by the Supreme Court when "a United States court of appeals has entered a decision in conflict with the decision of another United States court of appeals on the same important matter . . . as to call for an exercise of [the Supreme] Court's supervisory power." SUP. CT. R. 10. The number of circuits whose decisions typically must join a divide for the Court to grant certiorari on a question is difficult to calculate, but studies consistently show that while not a guarantee, the Court is far more likely to review requests implicating a circuit court conflict, with such conflict cases comprising roughly one-third of the Court's docket. See Deborah Beim \& Kelly Rader, Evolution of Conflict in the Courts of Appeal 3 (2015 Midwest Pol. Sci. Ass'n Ann. Meeting, Preliminary Draft, (June 25, 2015)) http://dx.doi.org/10.2139/ssrn.2623304. The greater the number of circuits who have taken a position, the greater the likelihood a question will be resolved by the Court, although splits between only two circuits have still seen grants of certiorari. Id. at 19. And of course, the Court can only take up a question when there is an existing petition for certiorari. Id. at 2324.

171. These strongly felt political divides over sex and gender were reflected in the Fifth Circuit's recent justification for refusing to use a transgender person's preferred pronouns while claiming this refusal was a neutral and impartial position. See United States v. Varner, 948 F.3d 250, 256 (5th Cir. 2020) (noting federal courts today must "decide cases that turn on hotly-debated issues of sex and gender identity" and to use the pronouns litigants request, even for "the most benign motives[,]" may convey a court's "tacit approval" and raise the appearance of bias). In response, one commentator noted, "Good for Judge Duncan for both adhering to the letter of the law and for defiantly standing athwart the modern cultural Left's pernicious insistence on gaslighting the American citizenry into thinking that words may not mean what they so clearly do, in fact, mean." Josh Hammer, Culture War in the Courts: Federal Appeals Panel Rejects Transgender Pronouns, DAILY WIRE (Jan. 17, 2020), https://www.dailywire.com/news/culture-war-in-the-courts-federalappeals-panel-divides-on-transgender-pronouns [https://perma.cc/NJ9A-KW5B].

172. See discussion of medical bias, supra note 160 . 
explored, there is no consistent scientific evidence supporting normative changes is patently false. ${ }^{173}$ With this ideological struggle as background, the following are some arguments that could support a Supreme Court decision to follow Gibson.

First, like the Fifth Circuit, some will undoubtedly argue that the time has not yet arrived to recognize GCS as the "usual" medical care for severe GD. ${ }^{174}$ The Fifth Circuit argued that an incarcerated individual's suffering from a serious medical need does not alone activate Eighth Amendment protections without a "universal" medical consensus on treatment. ${ }^{175}$ If outdated assumptions about the binary nature of gender are still "usual" and there remain medical professionals who hold them, hormone therapy and surgery may be viewed as misguided "collaboration[s] with psychosis." 176 To avoid "indulg[ing] a [transgender] prisoner's improper self-image," the proper treatment is still long-recognized counseling to help the

173. The proof is in the results. Osborne, supra note 10, at 1652 ("SRS, in conjunction with cross-sex hormone therapy, has repeatedly been demonstrated to be associated with substantial reduction in GD symptoms, high levels of patient satisfaction, few significant complications, and minimal instances of regret." (citations omitted)). See NCD 140.3, Transsexual Surgery, DAB No. 2576, 1, 8 (U.S. Dep't Health \& Human Servs. May 30, 2014), https://www.hhs.gov/sites/default/ files/static/dab/decisions/board-decisions/2014/dab2576.pdf [https://perma.cc/GM694ANR] ("We have no difficulty concluding that the new evidence, which includes medical studies published in the more than 32 years since issuance of the 1981 report... demonstrates that [transgender] surgery is safe and effective and not experimental."); see also Green, supra note 2, at 61 (observing that, unfortunately, such new medical evidence can be hard to incorporate into the law with its focus on consistency and precedent guarded by judges who may feel compelled "to reduce complexity and even reject inconvenient new information" to privilege such values); What Does the Scholarly Research Say About the Effect of Gender Transition on Transgender Well-Being?, CORNELL U.: WHAT WE KNOW (2020), https://whatweknow.inequality.cornell.edu/topics/lgbt-equality/what-does-thescholarly-research-say-about-the-well-being-of-transgender-people/

[https://perma.cc/F9EB-7EQJ] (analyzing all peer-reviewed articles on gender transition published between 1991 and June 2017, with fifty-one studies concluding gender transition "improves the well-being of transgender people," four having "mixed or null findings," and none indicating "overall harm").

174. See Bourcicot, supra note 10, at 311 ("Challengers who claim that they need surgical intervention should expect prisons and courts to resist ordering that taxpayer dollars be spent on various sex reassignment surgeries for a condition that is not well-understood by the general public and that is rare in society writ large.").

175. Gibson v. Collier, 920 F.3d 212, 219-20 (5th Cir. 2019).

176. Green, supra note 2, at 25-26; see also Levine, supra note 36, at 241 (suggesting some transgender imprisoned persons will "sacrifice genitalia to give a new organizing purpose to life" based on this pathology); Lindevaldsen, supra note 37 , at 26 (arguing GD is a belief that does not align with reality, and "an anorexic is not encouraged to believe she is overweight and in need of losing weight; she is encouraged to attain a proper understanding of the role of food in her life and a healthy self-perception"). But cf. Osborne, supra note 10, at 1657 (arguing "it is legally and ethically obligatory to make SRS available to inmates for whom it is medically necessary"). 
transgender individual accept their birth-sex gender. ${ }^{177}$ However, this withholding of WPATH Standards of Care because its treatments have not become "usual" enough or because they grate against beliefs about binary gender norms belongs to normative outliers. ${ }^{178}$ Ignoring the robust medical consensus that our understanding of gender has changed-in the context of a judicial test that is supposed to do the very opposite on behalf of incarcerated persons-seems distastefully draconian. ${ }^{179}$ Given this backdrop, it is unlikely the Supreme Court would make a decision that does not genuinely grapple with the medical consensus that gender is not simply binary, counseling alone is not an adequate remedy for many with GD, and that GCS is the indicated treatment for some with acute GD. ${ }^{180}$

Perhaps some will argue WPATH Standards are the best possible medical care- the kind allegedly not necessary to provide to imprisoned persons. ${ }^{181}$ Best here seems to bleed into notions of elective care, but elective according to the public mob rather than the medical professional. For example, many emphasized that no taxpayer funding should be used for what is perceived as elective on a national petition demanding GCS be withheld from an imprisoned person. ${ }^{182}$ This denial of tax funding appears to scratch a flagrantly

177. Bendlin, supra note 20 , at 977 .

178. Edmo v. Corizon, Inc., 935 F.3d 757, 795 (9th Cir. 2019).

179. See Kosilek v. Maloney, 221 F. Supp. 2d 156, 160 (D. Mass. 2002) ("Prisoners in the United States have a right to humane treatment, including a right to adequate care for their serious medical needs. The Constitution does not protect this right because we are a nation that coddles criminals. Rather, we recognize and respect this right because we are, fundamentally, a decent people, and decent people do not allow other human beings in their custody to suffer needlessly from serious illness or injury.").

180. See Bendlin, supra note 20, at 979 (observing that "physicians, psychologists, judges, insurance agents, and even the Tax Court have weighed the evidence and have concluded that psychotherapy and psychiatric medications are not 'adequate' treatment in most [acute GD] cases").

181. Gibson v. Collier, 920 F.3d 212, 220 (5th Cir. 2019) (quoting Mayweather v. Foti, 958 F.2d 91, 91 (5th Cir. 1992) (noting imprisoned persons are not entitled to "the best [treatment] that money c[an] buy")). The "cheap and custodial quality of institutional care" has been justified by the belief that dependence is a "manifestation of an inferior and hopeless condition"- a condition being punished by a society embracing a protestant ethic seasoned with capitalism that believes to fail in the marketplace is to fail morally. CUSAC, supra note 4, at 129-30, 132.

182. No Sex Change for Prison Inmate, MoveOn, https://sign.moveon.org/ petitions/no-sex-change-for-prison?fbclid=IwAR1JeLDYvveUnzwCV5pKC-

ZzzgkuJA_RLu92jDdPre0IwtQBlofNkOr2us4\&r_hash=Hgoo1HVS\&source=s.icn.fb [https://perma.cc/BVV8-MXEL] (Carrie H. commented, "My tax dollars should never go to a convicted felon and child sex offender. He deserves nothing but a noose!" Spencer F. commented, "So if I do a crime, I get free cosmetic surgery? You loose [sic] 
retributivist itch where the guilty require punishment and that punishment should-overtly or implicitly-not avoid unpleasantness, particularly when it is less expensive to do nothing. ${ }^{183}$ This sentiment appears further exacerbated by the U.S. medical system where care is expensive and not guaranteed to its citizens, magnifying the perception that it is unjust and unfair that incarcerated persons are guaranteed free medications, psychotherapy, and even surgery. ${ }^{184}$ Nevertheless, difficult as this may be for some, once we have "tolled the bell" for an incarcerated person, "whether we like it or not, we have made him our collective responsibility. We are free to do something about him; he is not." 185 Additionally, the cost of GD treatments is "not unusually expensive" and is "actually less costly than other types of medical care that many prisoners receive." 186 And certainly mob standards are not medical standards; while the WPATH Standards recognize that the standards represent flexible guidelines, they are not intended to flex in contravention of "the many core principles that undergird

your rights to be a person and have rights when you commit a crime. You go to jail, to prison, and you have no rights. Have him pay for it himself when he gets out." Darlene D. commented, "[N]o way should taxpayers have to pay for this[]. 'IT" can pay for it when it gets out !!!!!!! [sic]") [https://perma.cc/XAK9-9PWA]. See generally Carol S. Steiker, Death, Taxes and-Punishment? A Response to Braithwaite and Tonry, 46 UCLA L. REV. 1793, 1797 (1999), including:

[Q] uite apart from serving as a subtle proxy for race or class hatred, harsh penological practices give people a new 'outsider' to hate, at a time when so many other outsiders have become more assimilated into society. Criminals, after all, are criminals.... Why it should be that people need some 'outsider' to hate and blame is a good question; but that people seem to need such a scapegoat is supported by much of human history.

(emphasis in original).

183. See Green, supra note 2, at 30 ("Institutionalized transphobia makes hatred, abuse, and inhumane treatment appear logical, natural, and even correct."). Green observes such naturalizing of transphobia shows our cost-conscious efficiency concerns are pretextual and are fundamentally about the scapegoating of transgender people because we fear violated boundaries. $I d$.

184. Bendlin, supra note 20, at 976 .

185. Id. at 978 (quoting Justice Blackmun, Address by the Chief Justice, 25 Rec. of the Ass'n of the Bar of the City of N.Y. 14, 17 (Mar. 1970 Supp.)). In an age of mass incarceration, America is a society of frenetic bellringing. As Dolovich observes, "[t]he greater society's appetite for imprisoning convicted offenders, the greater the burden." Supra note 18, at 972.

186. For example:

In Fields v. Smith, the court refuted and discredited the earlier Maggert dicta about the high cost of Gender Dysphoria treatments by pointing to evidence that the cost of hormone therapy varies between $\$ 300$ and $\$ 1,000$ per inmate per year whereas a common anti-psychotic drug costs the prison more than $\$ 2,500$ per inmate per year. Additionally, although genderreassignment surgery costs roughly $\$ 20,000$, the Department of Corrections "paid $\$ 37,244$ for one coronary bypass surgery and $\$ 32,897$ for one kidney transplant surgery."

Bendlin, supra note 18, at 965. 
the [Standards of Care]"-including non-pathologizing respect for nonconforming gender identities, care that reduces the distress of GD, a pursuit of GD knowledge, and treatment approaches tailored to specific patient needs and goals. ${ }^{187}$ These principles set the floor for care, not a ceiling below which we may choose lesser-but-stilladequate care. ${ }^{188}$ And it goes without saying that the long-term solution, of course, "is not to take away medical care from prisoners; it is to improve the availability of health care to all citizens." 189

Some will likely argue that the relevant harms are selfinflicted and common to this trans subpopulation, regardless of their housing situation and their course of medical treatment. 190 Correlation and causation cannot be easily untangled. What we know is that "[s]uicide is the leading cause of death in jails and $85[\%]$ of U.S. prison systems report that self-injurious behavior occurs at least once a week." 191 The Department of Justice notes that " $[t]$ he rates of inmate suicide are far higher than the national averages, and even higher still for special populations (including

187. WPATH, supra note 25 , at 3.

188. Even if some will argue that these WPATH principles do not set the floor, the pitting of tax savings against incarcerated health seems a gesture of short-term thinking, fostering a hostile separation that does not likely lend itself to postincarceration reintegration.

189. Bendlin, supra note 20, at 976.

190. See Osborne, supra note 10, at 1653 ("Community-dwelling persons with GD display an elevated prevalence of comorbid mental health problems, including mood disorders, anxiety disorders, and suicidality and these comorbid conditions do not significantly improve after SRS. Comorbid psychiatric conditions usually do improve, at least initially, after cross-sex hormone therapy. But while subsequent SRS usually ameliorates GD and increases overall life satisfaction, it appears to confer little or no additional improvement in other psychiatric symptoms." (citations omitted)); see also Levine, supra note 36, at 240, 242 (arguing that excuses are made for trans individuals to externalize rather than own their pathologies, where "[a]ny concurrent mental symptoms, such as anxiety states, suicidal preoccupations, suicide attempts, or substance abuse and unempathic aggression toward others, are viewed as consequences of social rejection," which, in turn, serves a misguided medical community that refuses to admit they are failing to appropriately treat depression).

\section{Further:}

Suicide is the leading cause of death in local jails, accounting for over onethird of jail deaths in 2013; it is less frequent in prison settings but still accounted for nearly 6[\%] of the deaths of people in state custody in 2013 . Although suicide rates in jail declined steadily from 129 deaths per 100,000 people in 1983 to 47 deaths per 100,000 in 2002, the rate of suicide increased by 12 [\%] between 2008 and 2013 and the suicide mortality rate is three times higher in jail populations than in either prison populations or the community.

Leah Pope \& Ayesha Delany-Brumsey, Creating a Culture of Safety: Sentinel Event Reviews for Suicide and Self-Harm in Correctional Facilities, VERA INST. OF JUST. 23 (2016), https://www.vera.org/publication_downloads/culture-of-safety-sentinelevent-suicide-self-harm-correctional-facilities/culture-of-safety.pdf

[https://perma.cc/LF6K-AEGL]. 
juvenile and LGBTI inmates) . . .."192 Self-harm in correctional settings lacks comprehensive national data, but research estimates "up to $15[\%]$ of adults and up to $24[\%]$ of young people engage in non-suicidal self-injury while in custody (defined as 'deliberate, selfinflicted tissue damage without intent to die'); rates are even higher when the person has a mental health disorder (up to 61[\%])." ${ }^{193} \mathrm{We}$ also know that GCS is not a cure-all, and suicide rates ten years after GCS are still high. ${ }^{194}$ Yet studies also show that depressive symptoms and suicidal ideation increase among imprisoned persons with GD when treatment is unavailable or when expression of their gender is constrained. ${ }^{195}$ Additionally, studies suggest that GCS provides relief to many experiencing GD and that regret rates are low. ${ }^{196}$ Moreover, this argument ignores what creates the duty for these medical professionals under the Eighth Amendment. The duty is created because the State limits and controls access to

192. Suicide in Corrections, NAT'L INST. CORR., U.S. DEP'T JUST., https://nicic.gov/suicide-in-corrections [https://perma.cc/9CN8-J28U]. See Holly Hedegaard, Sally C. Curtin \& Margaret Warner, Suicide Mortality in the United States, 1999-2017, NCHS DATA BRIEF NO. 330 Nov. 2018, at 1, https://www.cdc.gov/ nchs/data/databriefs/db330-h.pdf [https://perma.cc/M5TN-CZQV] (noting suicide has been the tenth leading cause of death for all ages in the U.S. since 2008 and has been on an increasing trend with approximately 14 deaths by suicide per 100,000 Americans in 2017 for a total of 47,173 suicides that year); see also McCauley, supra note 10, at 35 ("In the 2015 U.S. Transgender Survey, nearly $40 \%$ of transgender people reported experiencing serious psychological stress in the month before the survey (compared with 5\% of the U.S. population broadly), $7 \%$ attempted suicide in the year before the survey (compared with $0.06 \%$ of the U.S. population broadly), and $40 \%$ had attempted suicide in their lifetime (almost nine times the U.S. rate).").

193. Pope, supra note 191, at 3; see also Donna Gillies, Maria A. Christou, Andrew C. Dixon, Oliver J. Featherston, Iro Rapti, Alicia Garcia-Anguita, Miguel VillasisKeever, Pratibha Reebye, Evangelos Christou, Nagat Al Kabir \& Panagiota A. Christou, Prevalence and Characteristics of Self-Harm in Adolescents: Meta-analyses of Community-Based Studies 1990-2015, 57 J. AM. ACAD. CHILD AdolEsCENT PSYCHIATRY 733, 736-37 (2018) (finding about 17\% of adolescents will self-harm in their lifetime, with self-cutting as the most common form of self-harm); Tori DeAngelis, Who Self-Injures?, 46 AM. PsYchOL. Ass'N 60, 60 (2015), https://www.apa.org/monitor/2015/07-08/who-self-injures [https://perma.cc/P4B5$4 \mathrm{~L} 7 \mathrm{~L}]$ (finding that adults have a reported lifetime self-harm rate of about 5\%).

194. See Cecilia Dhejne, Paul Lichtenstein, Marcus Boman, Anna L.V. Johansson, Niklas Långström \& Mikael Landén, Long-Term Follow-Up of Transsexual Persons Undergoing Sex Reassignment Surgery: Cohort Study in Sweden, 6 PLoS ONE, e16885, 2011, at 2 (citing various follow-up studies noting post-GCS suicides were still attempted and/or completed at varying rates, with more studies needed); see also Osborne, supra note 10, at 1653 (noting GCS "appears to confer little or no additional improvement in other psychiatric symptoms").

195. Osborne, supra note 10 , at 1655.

196. WPATH, supra note 25 , at 8 (noting recent GCS satisfaction rates were at $87 \%$ for $\mathrm{MtF}$ patients and $97 \%$ for FtM patients, with the regret rate hovering around $1 \%$ ); see also Osborne, supra note 10, at 1652 (observing GCS has repeatedly been demonstrated to reduce GD symptoms and produce both high patient satisfaction and low regret rates). 
medical care, assuming responsibility for each incarcerated person's wellbeing 197 _even for subpopulations who might not choose (or be able to choose) to access such care in the general population, or who enter prison terminally ill. For example, take an individual with poorly managed asthma, a history of self-cutting, terminal cancer, or someone who, through the effects of poverty, has delayed a necessary surgery. These individuals, once incarcerated, are no less entitled to necessary medical care simply because they would have suffered constricted breathing, self-inflicted injuries, an inevitably painful course of treatment ending in death, or the pain of a surgery's delay outside of the institution. As soon as the State assumes responsibility for incarcerated persons, the Eighth Amendment applies without regard to medical outcomes that might have occurred in an imprisoned person's non-incarcerated alternative reality.

Others may argue that imprisoned persons are an atypical subpopulation of the trans community, and therefore, transgender standards of health care simply were not designed-nor can they be-with such persons in mind. ${ }^{198}$ This is directly countered by the WPATH Standards themselves which clearly intend to encompass the transgender prison population. ${ }^{199}$ Some argue that we are in a catch-22 because in order to determine what medical standards of care are appropriately tailored to imprisoned transgender persons, we must be allowed to do medical experimentation on those imprisoned subjects, which would be viewed as unethical.200 However, this argument merely points out the inevitable knowledge gap all medicine faces since we also consider children, pregnant women, fetuses, mentally disabled persons, and economically or educationally disadvantaged individuals to be unable to consent to studies, though some argue we should rethink this ethical

197. Bendlin, supra note 20, at 977 ("When the state takes someone into custody and deprives [them] of the ability to take care of [themself], the state assumes some duty to provide for [their] basic needs such as food, shelter, clothing, personal safety, and medical care.").

198. Osborne, supra note 10, at 1651 ("Inmates who seek treatment for GD typically display little resemblance to the patients who present for treatment in the community, and prison life bears little resemblance to life in the community. The [Standards of Care] were not developed with the complexities, vulnerabilities, and life circumstances of incarcerated persons in mind.").

199. WPATH, supra note 25, at 67 (noting the WPATH Standards are applicable irrespective of housing situations, including for gender-nonconforming people living in institutions).

200. Levine, supra note 36, at 241. 
paradigm. ${ }^{201}$ Furthermore, this argument does not provide any reason to deviate from the currently-accepted standards of care for the broader, non-incarcerated trans population while we await better research. ${ }^{202}$ Some counter this by arguing that applying these same standards may actually be harmful because imprisoned persons in particular are not able to satisfy the WPATH criterion requiring twelve months of living as the desired gender outside of the artificial world of the penal institution. ${ }^{203}$ As the argument goes, incarcerated persons are not in their "real life." Yet the regrettably disproportionate rate of trans individuals who face incarceration makes this argument less weight-bearing; for too many transgender Americans, prison is real life. ${ }^{204}$

Finally, some who admit binary sex does not reflect reality will argue that fundamentally remaking the gendered systems and spaces of criminal justice is impractically cost prohibitive, even if there might be resulting benefits. Recognizing transgender imprisoned persons as their identifying gender over their biological sex would necessitate "a fundamental reconceptualization of [a] societal order" built on the male/female binary. ${ }^{205}$ The jail or prison that acknowledges a transgender person's trans-gender must decide

201. See, e.g., Stephanie S. Park \& Mitchell H. Grayson, Clinical Research: Protection of the "Vulnerable"?, 121 J. AllERGY ClinICAL IMMUNOLOGY 1103, 110304 (2008).

202. After all, we provide medical treatment to women in the U.S. when, by this logic, we should stop treating them for a variety of issues since medical studies have used male subjects to such an extent that even common diseases are poorly understood for women - for example, heart disease. See Barouch, supra note 160.

203. Edmo v. Corizon, Inc., 935 F.3d 757, 774 (9th Cir. 2019) (noting one of the reasons Eliason believed the WPATH Standards for GCS were not satisfied was "because Edmo had not lived in her identified gender role for 12 months outside of prison"); see also Osborne, supra note 10, at 1659 (observing changes in life circumstances can affect the severity of GD symptoms and the desirability of GCS, potentially leading to post-release regret about having undergone GCS).

204. See McCauley, supra note 10, at 34 (noting the high rates of incarceration for transgender people); see also Osborne, supra note 10, at 1659 (observing the prison environment can be a stabilizing space free from restraining forces of a transgender person's outside relationships, allowing individuals to more freely confront feelings of GD, acquire knowledge and language about their experience, and find transgender role models).

205. Richard F. Storrow, Naming the Grotesque Body in the "Nascent Jurisprudence of Transsexualism", 4 MicH. J. GENDER \& L. 275, 302 (1997) (arguing fear of such social upheaval "may be a major factor in the law's lack of compassion for [transgender individuals]"); see also Green, supra note 2, at 72-73 (arguing courts find it "difficult to permit the grotesque to mingle with the orderly social body that the law attempts to preserve" by recognizing transgender people "as full members of society"). 
how they fit into the existing male/female system or must change the system itself. 206

Housing locations, privacy, staffing, searches, safety, and a host of other penitentiary protocols are built on the binary sex system. ${ }^{207}$ It is undeniable the forward march of norms in the area of gender identity will inevitably create a host of costly challenges for our institutions across society. ${ }^{208}$ Such costs are likely more easily quantifiable than the benefits of moving to systems that better represent the reality of our genders. While these big picture concerns may drive and even be articulated by the Supreme Court, such a view strays too far afield from the individually-situated facts of a particular incarcerated person who will raise their need for GCS in a real case that prompts the review. The settled jurisprudence of the Eighth Amendment's medical necessity doctrine requires a "fact-specific analysis" of an incarcerated individual's symptoms and risks of serious harm, available accepted treatments, and whether the treatment provided "was the product of sound medical

206. The American Medical Association recently issued a press release that "challenge[d] the status quo of prisons and jails in the United States that house transgender prisoners according to their birth or biological sex[,] . . urg[ing] that housing policies be changed to allow transgender prisoners to be placed in correctional facilities that are reflective of their affirmed gender status." Press Release, AMA Urges Appropriate Placement of Transgender Prisoners, AM. MED. ASS'N (June 11, 2018), https://www.ama-assn.org/press-center/press-releases/amaurges-appropriate-placement-transgender-prisoners [https://perma.cc/W9A89YWD].

207. Benish A. Shah, Lost in the Gender Maze: Placement of Transgender Inmates in the Prison System, 5 J. RACE, GENDER \& ETHNICITY 39, 42-43 (2010) (providing a helpful overview of the many existing sex-based prison policies that determine prison placements).

208. Gender-neutral restrooms are probably the spaces most widely associated with gender identity changes in American society today. Jeannie Suk Gersen, Who's Afraid of Gender-Neutral Bathrooms?, NEW YORKER (Jan. 25, 2016), https://www.newyorker.com/news/news-desk/whos-afraid-of-same-sex-bathrooms [https://perma.cc/56KR-Z856] ("One practical reason we can't change to unsegregated bathrooms overnight is that municipal, state, and federal legal codes, many with origins in the nineteenth century, mandate that there be separate facilities for each sex, in businesses and places of work."). While the author was writing this Note, the University of Minnesota Law School was in hot debate over the need for more easily accessible gender-neutral restrooms for its staff and students. Disappointingly, the restrictions of state building codes were cited as the ultimate basis for taking little remedial action. The Administration noted:

[W]e learned that we were constrained from pursuing efforts to convert any

of the building's multi-stall restrooms into gender-inclusive restrooms by current state building code requirements. The state building code mandates specific plumbing count requirements that remain gender-specific and also control restroom-signage requirements. . . . Should the building code change, we will again explore converting our multi-stall restrooms.

E-mail from Garry Jenkins, Dean, Univ. of Minn. Law Sch., to the Law School Community (Jan. 28, 2020, 12:21 PM) (on file with author). 
judgment, negligence, or deliberate indifference." 209 Thus, to counter the inevitable future need to de-gender our institutions would require the Supreme Court to whittle the medical necessity doctrine away to nothing against its own precedent, which it is unlikely to do. There are larger implications for acknowledging the rights of transgender persons, but the doctrine of medical necessity is too strong and specific to allow for these big-picture fears to trump.

\section{Hearing and Seeing What Edmo and Gibson Are Telling Us}

This final Part will take a step back to look at the broader cultural and legal landscape in which the Edmo and Gibson decisions were made. Rooting ourselves in the reality of what Edmo and Gibson experienced as incarcerated transgender people-a pain-filled reality so acute as to prompt self-injury-demonstrates that medical necessity is not effectively actualizing the Eighth Amendment. This Part will then explore that dissonance and its consequences in American society and the legal profession, campaigning for the adoption of proxies that better close the gap between constitutional ideals of equality and independence and our consciences.

\section{A. The Mistake of Dismissing Imprisoned Transgender People's Experiences}

At this point, some readers may agree that the Supreme Court should probably let this imprisoned subpopulation have their surgeries, end of discussion. Actually, the discussion is just beginning. Edmo and Gibson are liminal bodies in liminal legal spaces, and the liminal spaces are often where we can confront the lines we have artificially drawn to see whether or not they reflect reality. ${ }^{210}$

The problem with dismissing experiences not considered "central" in American society is that it gives us cultural myopathy. To see ourselves, we need to listen to Edmo and Gibson. America's prison system has demonstrated since its Puritan beginnings that,

209. Edmo v. Corizon, Inc., 935 F.3d 757, 794 (9th Cir. 2019).

210. To say "[i]t is emphatically the province and duty of the judicial department to [s] ay what the law is" puts courts in the business of drawing these lines that may seem rational, arbitrary, inclusive, or exclusive, depending on where you sit in relation to them - and ultimately allows courts to create and reinforce what we express and repress in American society. Marbury v. Madison, 5 U.S. (1 Cranch) 137, 177 (1803). 
in America-contrary to the word of the Declaration of Independence-all people are not equal; dependence is preferred for norm-transgressors. ${ }^{211}$ Further, history has shown that what we condone as normatively acceptable for our incarcerated members tends to become a part of our norms beyond prisons: punishment creeps out into our culture. ${ }^{212}$ We may say our American values are equality and independence, but if we foster inequality and dependence in our prisons, we foster it in the places we work, the schools we and our kids attend, the scientific discoveries we sponsor and pursue, and the art that frames our understanding of life. ${ }^{213}$ If the edges are bleeding, the center will eventually be red too. Edmo and Gibson tell us the edges are bleeding.

\section{B. Proxies for Proxies for Proxies: Remembering What Our Doctrines and Laws Signify}

At some point, we need to remember what things stand in for to see how our proxies relate to our original intent. ${ }^{214}$ Are $E d m o$ and Gibson telling us medical necessity is an effective proxy for the Eighth Amendment? Are they telling us medical necessity itself encapsulate proxies that should be recognized in their own right under the Eighth Amendment? Are they reminding us what the Eighth Amendment itself is a proxy for in American society?

\section{i. Is Medical Necessity an Effective Proxy for the Eight} Amendment?

In Edmo and Gibson, the Ninth and Fifth Circuits used the same medical necessity test to come to different answers for

211. CUSAC, supra note 4, at 51.

212. Id. at 73-74, 163 ("Ideas about punishment and punishment practices are not static things. Not only do they evolve, they also move laterally through society, affecting our popular culture and American homes, religious institutions, and schools.").

213. For examinations of this phenomenon in art, see, e.g., CUSAC, supra note 4 , at 186-87 (observing radio and television have historically been-and are-full of "cop shows" such as Law and Order, CSI, Criminal Minds, and more-all including enactments of violent crimes and implicitly or explicitly violent punishments) and JARVIS, supra note 18 (considering the centrality of punishment in American literature, including in The Scarlet Letter and Herman Melville's works, as well as in various films, including The Shawshank Redemption and Dead Man Walking).

214. This is not in the originalist sense of a return to dictionary definitions from centuries ago or letters between Founding Fathers to reach a regressive outcome that resists normative change and typically maintains power for a status quo of privileged symbolic and literal bodies. See Bourcicot, supra note 10, at 290 (noting the Supreme Court struggled to pin down the meaning of "cruel and unusual" from the beginning because these are aspirational concepts that resist being fixed to a past moment or meaning). 
individuals with similar experiences of acute GD. Interestingly, where they aligned was in the need to answer why medical necessity is effectively working to protect Eighth Amendment obligations, labors suggesting that medical necessity alone fails to stand in entirely for the Eighth Amendment (and this Note will argue, for the American conscience). Both circuits argued medical necessity was an effective proxy, but for different reasons-and held up strikingly different cultural mirrors for Americans in doing so.

The Edmo court emphasized longevity and harm prevention. Judges McKeown, Gould, and Lasnik noted that the values embodied by the Eighth Amendment have been upheld through the doctrine of medical necessity for forty years by the Supreme Court. 215 The suggestion is that stare decisis is confirmation over time that we have located a correct proxy for what is cruel and unusual. The test is working because it can adapt over time to "area[s] of increased social awareness" and our "developing understanding" of medical conditions and treatments. ${ }^{216}$ In addition to this, the court located irreparable harm at the center of what the Eighth Amendment seeks to prevent. The irreparable harm at stake for Edmo was both physiological and constitutional. Physiologically, her "severe, ongoing psychological distress and the high risk of selfcastration and suicide she face[d] absent surgery constitute[d] irreparable harm." ${ }^{217}$ Additionally, deprivation of adequate medical care violating the Eighth Amendment "cannot be adequately remedied through damages and therefore generally constitute[s] irreparable harm." ${ }^{18}$ Thus, the Ninth Circuit argues that because medical necessity prevents irreparable harms as we understand them over long periods of time, the test remains a good proxy for the Eighth Amendment.

The Gibson court focused on usualness and had no qualms about suggesting the Eighth Amendment allows for the usual cruelties. Judge Ho argued that behind medical necessity-and before indifference to it-are those actions or inactions American society sets its face against. ${ }^{219} \mathrm{It}$ is not the Fifth Circuit that is cruel; it is the American people who are cruel. ${ }^{220}$ The court argued medical necessity is a numbers game to be played, with enough momentum from lower and sister courts to creep forward the line until both

215. Edmo v. Corizon, Inc., 935 F.3d 757, 766 (9th Cir. 2019).

216. $I d$. at 803 .

217. Id. at 797-98.

218. Id. at 798 (quoting Nelson v. NASA, 530 F.3d 865, 882 (9th Cir. 2008)).

219. Gibson v. Collier, 920 F.3d 212, 227 (5th Cir. 2019).

220. $I d$. 
cruel and unusual are satisfied, as the court argued has occurred in the halted practice of executing juveniles. ${ }^{221}$ The Gibson majority made much of the need for consensus, even as it averted its gaze from the already existing evidence of medical consensus that would sway the Ninth Circuit a few months later. In this way, the Gibson court exposed the weakness of the legal doctrine of medical necessity as a proxy for what is cruel and unusual: changing norms are resisted, especially by society's institutions. ${ }^{222}$ To delay the demons of change, the Fifth Circuit compelled itself to needlessly address the merits of the case. ${ }^{223}$ The court's focus on usualness is strained by the existing WPATH Standards and the District of Idaho's Edmo decision, so the court belabored the past Kosilek decision and resurrected Justice Scalia's originalist ghost to produce its desired outcome: "It cannot be deliberately indifferent to deny in Texas what is controversial in every other state." 224 The numbers are just not there yet, and the court argued this shows why medical necessity is a good proxy for the Eighth Amendment. In other words, medical necessity works because, while it allows cruelty, it does not allow unjustifiable cruelty.

Thus, where the Ninth Circuit celebrated medical necessity as an effective proxy for keeping imprisoned Americans free from irreparable harms, the Fifth Circuit lauded medical necessity for its ability to precisely reflect the unvarnished reality of American mores. In the Ninth Circuit's America, we do not forsake protecting the fundamental rights of Americans when those lives are experienced behind prison bars. In the Fifth Circuit's America, we offer only those protections that minimum decency allows; if you lose your liberty, the pursuit of happiness and even life may also be withheld. ${ }^{225}$ If the doctrine of medical necessity can give us two such different Americas, ${ }^{226}$ then there is room to question whether medical necessity is the standard-bearing Eighth Amendment proxy Justice Blackmun envisioned. ${ }^{227}$

221. Id

222. Dolovich observes that the courts themselves have "become sites of institutional cruelty." Supra note 18, at 978.

223. Gibson, 920 F.3d at 218, 226-27.

224. Id. at 228 .

225. DECLARATION OF INDEPENDENCE, supra note 3.

226. This Note argues the Fifth Circuit incorrectly applied the doctrine, and therefore, it is difficult to make a firm conclusion that medical necessity is or is not an effective proxy for the Eighth Amendment based on these two cases.

227. Jackson v. Bishop, 404 F.2d 571, 579 (8th Cir. 1968). 
ii. Does Medical Necessity Encapsulate Proxies that Should be Recognized in Their Own Right?

If we de-medicalize the symptoms of Edmo and Gibson's acute gender dysphoria, we are left with depression of the desperate strain that attempts escape or solution by self-harm and/or suicide. ${ }^{228}$ Our proxies for cruel and unusual punishment, it follows, should guard against imposing circumstances that are likely to result in higher rates of self-harm and suicidality for incarcerated persons. ${ }^{229}$ These life threats are, themselves, appropriate proxies for the Eighth Amendment, wholly apart from medical necessity. ${ }^{230}$ If the State is imposing circumstances it knows or should know increase the likelihood of self-harm and/or suicidality to statistically significant levels, it should be found deliberately indifferent to providing appropriately dignified and humane conditions for incarcerated persons in violation of the Eighth Amendment. ${ }^{231}$

Such a proxy would, for example, make the practice of solitary confinement a violation of a person's Eighth Amendment rights. Solitary confinement was first introduced in American prisons under the belief that the right conditions for repentance could correct the wayward criminal soul. ${ }^{232}$ It soon became apparent that

228. Edmo v. Corizon, Inc., 935 F.3d 757, 767 (9th Cir. 2019); Gibson, 920 F.3d at 217.

229. But see Levine, supra note 36, at 244 (arguing the State should not become one more victim at the hands of imprisoned persons' manipulative personalities since imprisoned individuals will make threats of self-injury that may be just as likely rooted in a "motive to annoy" as they are in an expression of "genuine psychological pain").

230. To some extent we have recognized this, since the subjective threshold of medical necessity is typically met when there is potential deprivation of life itself or infliction of permanent injuries. See McCollum v. Mayfield, 130 F. Supp. 112, 115 (N.D. Cal. 1955) ("A refusal to furnish medical care when it is clearly necessary, such as is alleged here, could well result in the deprivation of life itself; it is alleged that plaintiff suffered paralysis and disability from which he will never recover. This amounts to the infliction of permanent injuries, which is, to some extent, a deprivation of life, of liberty and of property. Since these rights are protected by the Fourteenth Amendment to the Federal Constitution, the complaint sufficiently alleges the deprivation of a right, privilege or immunity secured by the Constitution and laws of the United States.").

231. MUSHLIN, supra note 17, at 453-54 ("The fact that suicide is an action taken by the inmate is irrelevant; there is a clear duty "to protect prisoners from selfdestruction or self-injury."' (quoting Lee v. Downs, 641 F.2d 1117, 1121 (4th Cir. 1981)) (citing Martin v. Harrison Cnty. Jail, 975 F.2d 192, 192-93 (5th Cir. 1992) (holding that prison guards had a duty to try to stop suicide and, when they struck an imprisoned person who was attempting self-injury, there was no liability))).

232. CUSAC, supra note 4 , at 48-49, 59 . 
solitary confinement induced suicide. ${ }^{233}$ The Supreme Court in 1890 observed that as a result of solitary confinement:

A considerable number of the prisoners fell, after even a short confinement, into a semi-fatuous condition, from which it was next to impossible to arouse them, and others became violently insane; others, still, committed suicide; while those who stood the ordeal better were not generally reformed, and in most cases did not recover sufficient mental activity to be of any subsequent service to the community .... .234

One hundred years later in the 1990s, the use of solitary confinement increased again — despite being previously found cruel and ineffective. ${ }^{235}$ Research conclusions about solitary confinement at the turn of this century find "[t]here are few if any forms of imprisonment that appear to produce so much psychological trauma and in which so many symptoms of psychopathology are manifested." 236 Prisons and courts continue to acknowledge these known facts. ${ }^{237}$ Nevertheless, the practice of solitary confinement

233. Id. at 54, 63; see Craig Haney, Mental Health Issues in Long-Term Solitary and "Supermax" Confinement, 49 CRIME \& DELINQ. 124, 133-34 (2003) (observing common psychopathological symptoms of isolation include ruminations or intrusive thoughts, irrational anger, an oversensitivity to external stimuli, confused thought processes, social withdrawal, chronic depression and sadness, emotional flatness, fainting spells, nervousness and anxiety, sweaty palms, chronic lethargy, headaches, troubled sleep, nightmares, trembling, difficulties with attention and memory, headaches, heart palpitations, mood swings, talking to oneself, violent fantasies, perceptual distortions, hallucinations, and thoughts of suicide).

234. In re Medley, 134 U.S. 160, 168 (1890).

235. CuSAC, supra note 4 , at 241. Note that this is an example of the cyclical nature of punishment norms.

236. Haney, supra note 233, at 125 . Haney also explains:

In assessing the mental health concerns raised by supermax prisons, it is important to acknowledge an extensive empirical literature that clearly establishes their potential to inflict psychological pain and emotional damage. Empirical research on solitary and supermax-like confinement has consistently and unequivocally documented the harmful consequences of living in these kinds of environments. Despite some methodological limitations that apply to some of the individual studies, the findings are robust.

Id. at 130. That such clear, robust, longstanding evidence of irreparable harm continues to escape protection under the Eighth Amendment is evidence self-injury should be made a proxy in its own right.

237. See, e.g., Palakovic v. Wetzel, 854 F.3d 209, 229 (3d Cir. 2017) (holding prison officials were deliberately indifferent to an imprisoned person's rights when they knew of his history of self-harm and suicide attempts and yet still "repeatedly subjected [him] to the harsh and unforgiving confines of solitary confinement" even though their own prison policy acknowledged "solitary confinement can increase the potential for suicide due to the 'inherent stress' of those conditions"). 
continues-as does the need for better proxies for Eighth Amendment violations.

iii. What is the Eighth Amendment a Proxy for in American Society?

The Eighth Amendment and medical necessity are ultimately proxies for the American conscience. The society we shape with these proxies is a signifier for our moral identity; we make the culture we are, and in turn, it makes us. "Humaneness, empathetic comprehension of an individual's suffering, belief in a person's ability to change[,] ... elections where racial minorities have a voice equivalent to their numbers, communal generosity to the vulnerable, and, finally, democracy ... are all at risk" when we dull our consciences to the private pain of our incarcerated fellow human beings. ${ }^{238}$ This is true even if it is not the accepted opinion of our political group, religious text, professional association, or lived bodily experience. 239

The Eighth Amendment and medical necessity are also proxies for the American legal professional's conscience. Perhaps nowhere (other than the minds and bodies of its victims) is the dissonance between American conscience and Eighth Amendment proxy felt more keenly than in our judges. These individuals are asked to set aside their own consciences in favor of proxies that, despite even the best intentions, may in fact be cruel. Worse, they must legitimize those proxies, "legally transforming the cruelty of institutional indifference to prisoners' suffering into not-cruelty by validating the harmful effects of that indifference as consistent with the Eighth Amendment." 240 Herein lies a moral rot: We have a toxic legal confirmation bias where we insist judges "suppress any instinctive sympathy they may have for fellow human beings who have experienced gratuitous suffering" to enforce our legal standards and to avoid even the appearance of judicial bias-regardless of the cost

238. CuSAC, supra note 4, at 255.

239. In the U.S. in the year 2020 , our consciences (and scientific facts) are buried under our confirmation biases, and our citizenry is as divided as traditional gender binary norms. See Douglas T. Kenrick, Adam B. Cohen, Steven L. Neuberg \& Robert B. Cialdini, The Science of Antiscience Thinking, 319 SCI. AM. 36 (2018); Bradley Jones, Republicans and Democrats Have Grown Further Apart on What the Nation's Top Priorities Should Be, PEW Rsch. CTR. (Feb. 5, 2019), https://www.pew research.org/fact-tank/2019/02/05/republicans-and-democrats-have-grown-furtherapart-on-what-the-nations-top-priorities-should-be/ [https://perma.cc/X7RU-CYY7].

240. Dolovich, supra note 18, at 978. 
of the suffering that purchases it. ${ }^{241}$ When consistent, impartial justice requires a dulling of conscience, it is not justice.

$E d m o$ and Gibson invite a reawakening of the consciences of Americans and their legal professionals. "Only the repeated experience of hearing persons with genital anatomic GD describe their anguish is likely to help others understand the psychological reality of this condition and the medical necessity of SRS as a treatment for it." 242 Arguably, this must be paired with listening to trans voices who feel this anguish, but debate the value of its medicalization. ${ }^{243}$ And above all, this must be done by listening to, looking at, and acknowledging the individual pain being experienced. If we acknowledge our biases and listen to the experiences of Americans across the expanses of sex, race, and gender, we will see the effects of punishment produced by-and producing-our fable of what it means to be American. ${ }^{244}$ This

241. Id. ("[C]ourts play a key role in sustaining and even creating the cruel conditions currently found in many American prisons and jails. In this sense, judges, too, become agents of cruelty. Just as prison officials learn cruelty through repeated exposure to prisoners in a context that denies their shared humanity, judges develop a cruel disposition toward prisoners through the repeated demand that they validate as not cruel conditions that are clearly at odds with the state's carceral burden. Existing constitutional standards require courts to find for the state even when prisoners face obvious risks of serious physical or psychological harm."); see also United States v. Varner, No. 19-40016, 2020 U.S. App. LEXIS 1346, at *10 (5th Cir. Jan. 15, 2020) ("Even [the] appearance of bias, whether real or not, should be avoided.").

242. Osborne, supra note 10, at 1653.

243. See, e.g., Alice Dreger, Why Gender Dysphoria Should No Longer Be Considered a Medical Disorder: It Does More Harm than Good, PAC. STANDARD MAG. (June 14, 2017), https://psmag.com/social-justice/take-gender-identity-disorder-dsm68308 [https://perma.cc/M4XJ-4QAF].

244. Herald, supra note 27 at 169-70 (observing that cognitive bias causes us to resist new information if it counters long-held beliefs, both by disregarding information that contradicts our beliefs and by adopting denial strategies to avoid re-examining those beliefs). These biases include how we understand our bodies. "How we see, read, and interpret the human body is filtered through many forms of knowledge and belief such as education, personal experience, cultural standards, racial prejudice, sexism, religious edicts and moral principles." Green, supra note 2, at 30. Speaking to the legal community's bias-stoppered ears, it is important to note that we are particularly susceptible to allowing legal precedent to give us a comforting confidence in siding with our preexisting biases. Id. at 33 . Too often "judges are selective in their acceptance of medical authority, ridicule and belittle [transgender] people, and are reluctant to grant them legal status in their affirmed sex because they have the "ability to explode settled social expectations and to destabilize the very social framework within which the law moves." $I d$. at 73 . When the legal profession refuses to overtly recognize the explicit rights of different classes, races, and sexes, it effectively reenacts a pattern of sustained colonialism. Id. at 85 . And yet, when it does overtly recognize these different rights, it may reinforce its social hierarchy in ways that limit those rights in the longer term. We must grapple with this. 
bodily pain, trauma, and death must be acknowledged, and we must create spaces for these silent centers of unspeakable hurt that we do not co-opt for medicine, or law, or science, or any other tool of methodology to justify being the content-controlling speaker that denies, excludes, contextualizes, or colonizes through narrationinstead of hearing and seeing. Only when we are willing to honestly acknowledge just what cruelty we are allowing can we contend with the dissonance between our American values of equality and independence and what our institutions-including the law-have created instead. ${ }^{245}$

\section{Conclusion}

America continues to criminalize and punish those whose very bodily existence transgresses "hegemonic fables of American national identity" through institutionalized forms of racism, misogyny, and transphobia. ${ }^{246}$ Yet ideas of equality and independence enshrined in the protections of America's Constitution provide tools to struggle with the resulting dissonances. Adree Edmo and Vanessa Lynn Gibson stand at the edge of American society as transgender, imprisoned people experiencing acute GD, but their legal cases in the Ninth and Fifth Circuits speak to the heart of some of the most central normative rifts that divide us-in particular here, beliefs and scientific evidence about sex and gender. Because of these divides, Edmo's access to Eighth Amendment protections and GCS stands in stark

245. For one example proposing how to do this work, see Neil Barsky, How to Fix Our Prisons? Let the Public Inside, MARShall Project (Dec. 17, 2019), https://www.themarshallproject.org/2019/12/17/how-to-fix-our-prisons-let-thepublic-inside [https://perma.cc/8MAF-CCA9]. In addition, there is no need to probe the American conscience without other reference points. See, e.g., G.A. Res. 217 (III) A, Universal Declaration of Human Rights (Dec. 10, 1948) and Charter of Fundamental Rights of the European Union, Dec. 12, 2007, 2007 O.J. (C 303) 1.

246. JARVIS, supra note 18, at 14; see also Green, supra note 2, at 29 ("The term 'transphobia' is often used to describe intolerance and aversion toward transgender ... people (in parallel to 'homophobia'). Transphobia is frequently characterized as a fear of difference, but it can be argued that transphobia is more rightly a fear of change. People fear the destabilization of gender and sex. They do not want to be 'fooled or deceived into thinking a person is something - or someonethat they are not entitled to claim to be."); Prusaczyk, supra note 6, at 1 (noting a recent study found that "those more conservative in ideology were more likely to display prejudice toward gender non-conformists in part due to their greater endorsement of binary gender beliefs[,]" suggesting such beliefs "function as a legitimizing myth to bolster existing hierarchical relations between gender conforming versus gender non-conforming people”). 
contrast to Gibson's denial of the same. ${ }^{247}$ The resulting dissonance in the application of an identical doctrine of medical necessity is, in part, due to the Fifth Circuit's misapplication of the doctrine; but more importantly, it is due to the conscience-dulling gap between medical necessity as a proxy for the Eighth Amendment, and the Eighth Amendment itself that stands in for our consciences.

This Note argues that we need to acknowledge the circumstances our criminal justice system creates that cause-or fail to stop-profound pain in the minds and bodies of imprisoned people. We must also acknowledge that this cruelty is able to slip through the medical necessity doctrine's cracks. ${ }^{248}$ Prison practices known to increase the likelihood of self-injury—such as the denial of GCS when it is indicated or the imposition of solitary confinement-cannot be allowed to continue based on doctrinal technicalities or vague fears. We must return to the Eighth Amendment afresh, acknowledging and submitting the mighty weight of bias we bring in all its myth-sustaining glory to the higher ideals to which we aspire as Americans and world citizens. We must actualize the normative changes our new understanding of sex and gender identity demand. This begins with a Supreme Court that should follow the Ninth Circuit's lead. It continues with new legal proxies that allow imprisoned people, lawyers, judges, and citizens to call ignoring unconscionable pain in prisons exactly what it is when we can do something about it (and the imprisoned cannot)cruel.

247. Edmo received her long-awaited GCS in July 2020. See Amanda Peacher, In a First, Transgender Inmate Receives Court-Ordered Surgery, INDIAN COUNTRY TODAY (Aug. 14, 2020), https://indiancountrytoday.com/news/in-a-first-transgenderinmate-receives-court-ordered-surgery-vZ-dsBYYxk2-jsRrwnejUA

[https://perma.cc/38PZ-9TSE].

248. See United States v. Carolene Prods. Co., 304 U.S. 144, 153 n.4 (1938) (observing that when "prejudice against discrete and insular minorities" has had the effect of "curtail[ing] the operation of those political processes ordinarily to be relied upon to protect minorities ... correspondingly more searching judicial inquiry" may be necessary). 